\title{
LEVEL II SCOUR ANALYSIS FOR BRIDGE 40 (ANDOVT00110040) on STATE ROUTE 11, crossing \\ LYMAN BROOK, ANDOVER, VERMONT
}

U.S. Geological Survey

Open-File Report 97-594

Prepared in cooperation with

VERMONT AGENCY OF TRANSPORTATION

and

FEDERAL HIGHWAY ADMINISTRATION 
LEVEL II SCOUR ANALYSIS FOR

BRIDGE 40 (ANDOVT00110040) on

STATE ROUTE 11, crossing

LYMAN BROOK,

ANDOVER, VERMONT

By MICHAEL A. IVANOFF \& RONDA L. BURNS

U.S. Geological Survey

Open-File Report 97-594

Prepared in cooperation with

VERMONT AGENCY OF TRANSPORTATION

and

FEDERAL HIGHWAY ADMINISTRATION 


\title{
U.S. DEPARTMENT OF THE INTERIOR BRUCE BABBITT, Secretary
}

\author{
U.S. GEOLOGICAL SURVEY \\ Gordon P. Eaton, Director
}

For additional information write to:

District Chief

U.S. Geological Survey 361 Commerce Way

Pembroke, NH 03275-3718
Copies of this report may be purchased from:

U.S. Geological Survey

Branch of Information Services

Open-File Reports Unit

Box 25286

Denver, CO 80225-0286 


\section{CONTENTS}

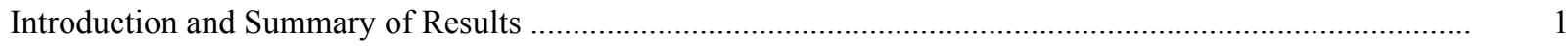

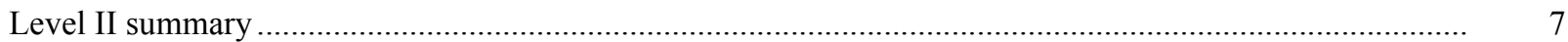

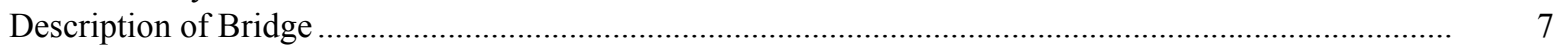

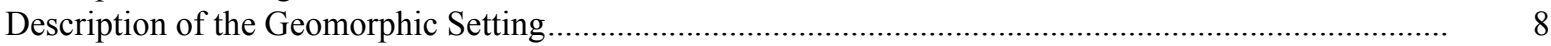

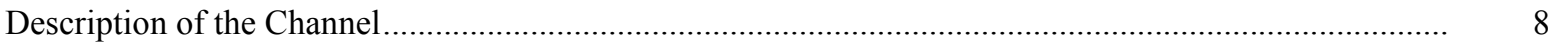

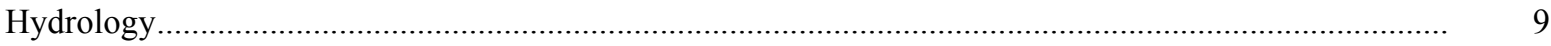

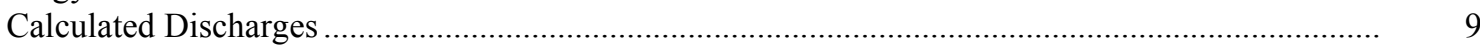

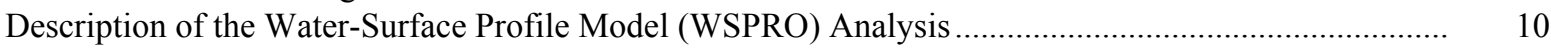

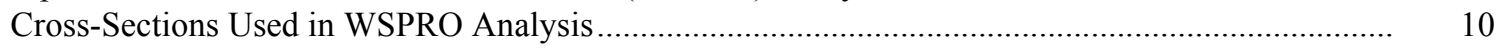

Data and Assumptions Used in WSPRO Model ...................................................................... 11

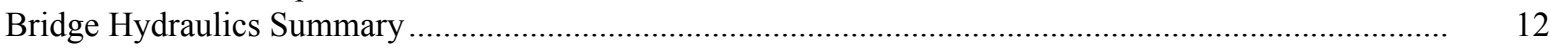

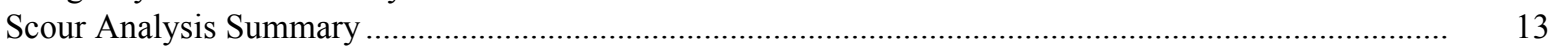

Special Conditions or Assumptions Made in Scour Analysis ...................................................... 13

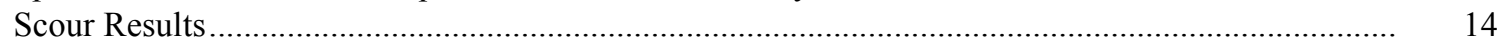

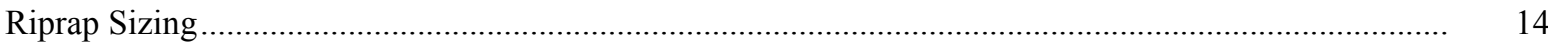

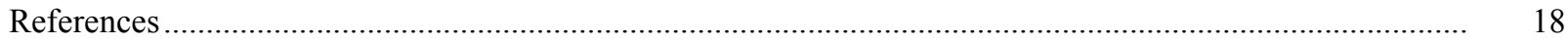

Appendixes:

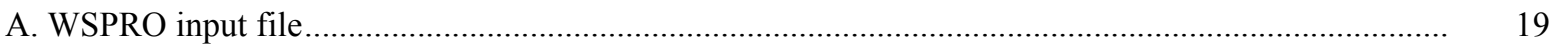

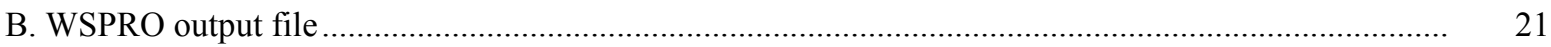

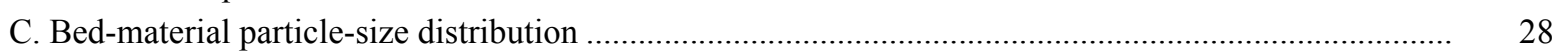

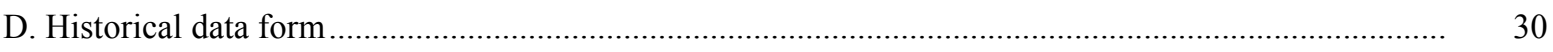

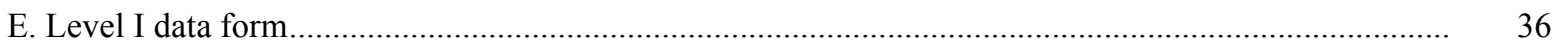

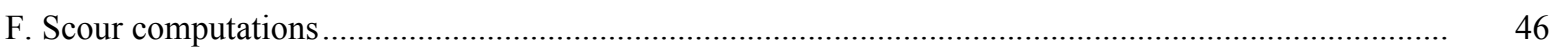

\section{FIGURES}

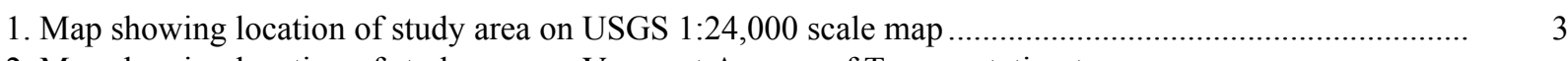

2. Map showing location of study area on Vermont Agency of Transportation town

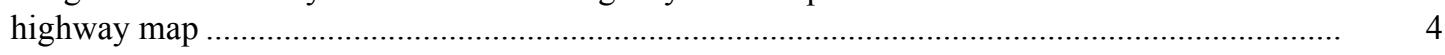

3. Structure ANDOVT00110040 viewed from upstream (September 9, 1996) .......................................... 5

4. Downstream channel viewed from structure ANDOVT00110040 (September 9, 1996)........................ 5

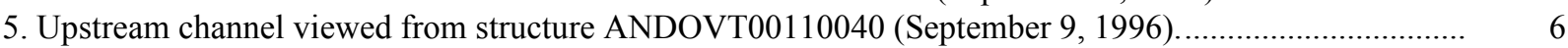

6. Structure ANDOVT00110040 viewed from downstream (September 9, 1996)................................... 6

7. Water-surface profiles for the 100- and 500-year discharges at structure

ANDOVT00110040 on State Route 11, crossing Lyman Brook,

Andover, Vermont.

8. Scour elevations for the 100- and 500-year discharges at structure

ANDOVT00110040 on State Route 11, crossing Lyman Brook,

Andover, Vermont.

\section{TABLES}

1. Remaining footing/pile depth at abutments for the 100-year discharge at structure

ANDOVT00110040 on State Route 11, crossing Lyman Brook,

Andover, Vermont

2. Remaining footing/pile depth at abutments for the 500-year discharge at structure

ANDOVT00110040 on State Route 11, crossing Lyman Brook,

Andover, Vermont 


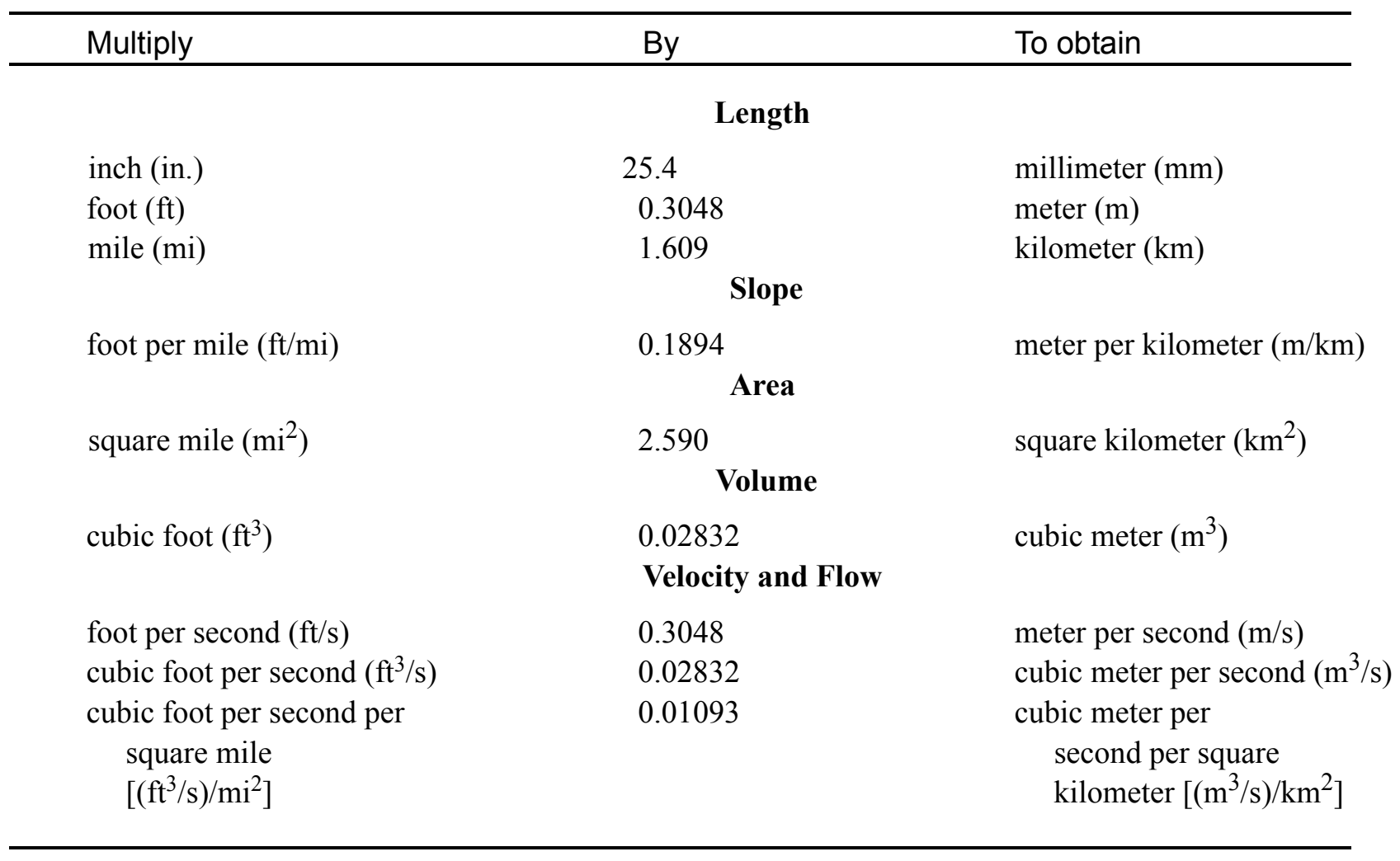

\section{OTHER ABBREVIATIONS}

$\begin{array}{lrlr}\mathrm{BF} & \text { bank full } & \text { LWW } & \text { left wingwall } \\ \mathrm{cfs} & \text { cubic feet per second } & \text { MC } & \text { main channel } \\ \mathrm{D}_{50} & \text { median diameter of bed material } & \text { RAB } & \text { right abutment } \\ \mathrm{DS} & \text { downstream } & \text { RABUT } & \text { face of right abutment } \\ \mathrm{elev} & \text { elevation } & \text { RB } & \text { right bank } \\ \mathrm{f} / \mathrm{p} & \text { flood plain } & \text { ROB } & \text { right overbank } \\ \mathrm{ft}^{2} & \text { square feet } & \text { RWW } & \text { right wingwall } \\ \mathrm{ft} / \mathrm{ft} & \text { feet per foot } & \text { TH } & \text { town highway } \\ \mathrm{JCT} & \text { junction } & \text { UB } & \text { under bridge } \\ \mathrm{LAB} & \text { left abutment } & \text { US } & \text { upstream } \\ \mathrm{LABUT} & \text { face of left abutment } & \text { USGS } & \text { United States Geological Survey } \\ \mathrm{LB} & \text { left bank } & \text { VTAOT Vermont Agency of Transportation } \\ \mathrm{LOB} & \text { left overbank } & \text { WSPRO } & \text { water-surface profile model }\end{array}$

In this report, the words "right" and "left" refer to directions that would be reported by an observer facing downstream. Sea level: In this report, "sea level" refers to the National Geodetic Vertical Datum of 1929-- a geodetic datum derived from a general adjustment of the first-order level nets of the United States and Canada, formerly called Sea Level Datum of 1929.

In the appendices, the above abbreviations may be combined. For example, USLB would represent upstream left bank. 


\title{
LEVEL II SCOUR ANALYSIS FOR BRIDGE 40 (ANDOVT00110040) ON STATE ROUTE 11, CROSSING LYMAN BROOK, ANDOVER, VERMONT
}

\author{
By Michael A. Ivanoff and Ronda L. Burns
}

\section{INTRODUCTION AND SUMMARY OF RESULTS}

This report provides the results of a detailed Level II analysis of scour potential at structure ANDOVT00110040 on State Route 11 crossing Lyman Brook, Andover, Vermont (figures $1-8)$. A Level II study is a basic engineering analysis of the site, including a quantitative analysis of stream stability and scour (U.S. Department of Transportation, 1993). Results of a Level I scour investigation also are included in Appendix E of this report. A Level I investigation provides a qualitative geomorphic characterization of the study site. Information on the bridge, gleaned from Vermont Agency of Transportation (VTAOT) files, was compiled prior to conducting Level I and Level II analyses and is found in Appendix D.

The site is in the Green Mountain section of the New England physiographic province in south-central Vermont. The $4.18-\mathrm{mi}^{2}$ drainage area is in a predominantly rural and forested basin. In the vicinity of the study site, the surface cover is pasture while the immediate banks have dense woody vegetation.

In the study area, Lyman Brook has an incised, straight channel with a slope of approximately $0.03 \mathrm{ft} / \mathrm{ft}$, an average channel top width of $42 \mathrm{ft}$ and an average bank height of $8 \mathrm{ft}$. The channel bed material ranges from gravel to boulder with a median grain size $\left(\mathrm{D}_{50}\right)$ of $86.0 \mathrm{~mm}(0.282 \mathrm{ft})$. The geomorphic assessment at the time of the Level I and Level II site visit on September 9, 1996, indicated that the reach was stable.

The State Route 11 crossing of Lyman Brook is a 28 -ft-long, two-lane bridge consisting of one 27-foot concrete tee-beam span (Vermont Agency of Transportation, written communication, March 29, 1995). The opening length of the structure parallel to the bridge face is $24.8 \mathrm{ft}$. The bridge is supported by vertical, concrete abutments with wingwalls. The channel is skewed approximately 0 degrees to the opening while the opening-skew-toroadway is 30 degrees. 
The scour protection measures at the site included type- 2 stone fill (less than 36 inches diameter) at the upstream end of the upstream right wingwall and the downstream ends of the downstream left and right wingwalls. There was also a stone wall along the top of the left bank from 36 to 76 feet upstream. Additional details describing conditions at the site are included in the Level II Summary and Appendices D and E.

Scour depths and recommended rock rip-rap sizes were computed using the general guidelines described in Hydraulic Engineering Circular 18 (Richardson and others, 1995). Total scour at a highway crossing is comprised of three components: 1) long-term streambed degradation; 2) contraction scour (due to accelerated flow caused by a reduction in flow area at a bridge) and; 3 ) local scour (caused by accelerated flow around piers and abutments). Total scour is the sum of the three components. Equations are available to compute depths for contraction and local scour and a summary of the results of these computations follows.

Contraction scour for all modelled flows ranged from 0.0 to $0.7 \mathrm{ft}$. The worst-case contraction scour occurred at the incipient-overtopping discharge which was more than the 100-year discharge. Left abutment scour ranged from 1.2 to $7.5 \mathrm{ft}$. The worst-case left abutment scour occurred at the 500-year discharge. Right abutment scour ranged from 5.2 to $6.7 \mathrm{ft}$. The worst-case right abutment scour occurred at the 100-year discharge.

Additional information on scour depths and depths to armoring are included in the section titled "Scour Results". Scoured-streambed elevations, based on the calculated scour depths, are presented in tables 1 and 2. A cross-section of the scour computed at the bridge is presented in figure 8. Scour depths were calculated assuming an infinite depth of erosive material and a homogeneous particle-size distribution.

It is generally accepted that the Froehlich equation (abutment scour) gives "excessively conservative estimates of scour depths" (Richardson and others, 1995, p. 47). Usually, computed scour depths are evaluated in combination with other information including (but not limited to) historical performance during flood events, the geomorphic stability assessment, existing scour protection measures, and the results of the hydraulic analyses. Therefore, scour depths adopted by VTAOT may differ from the computed values documented herein. 


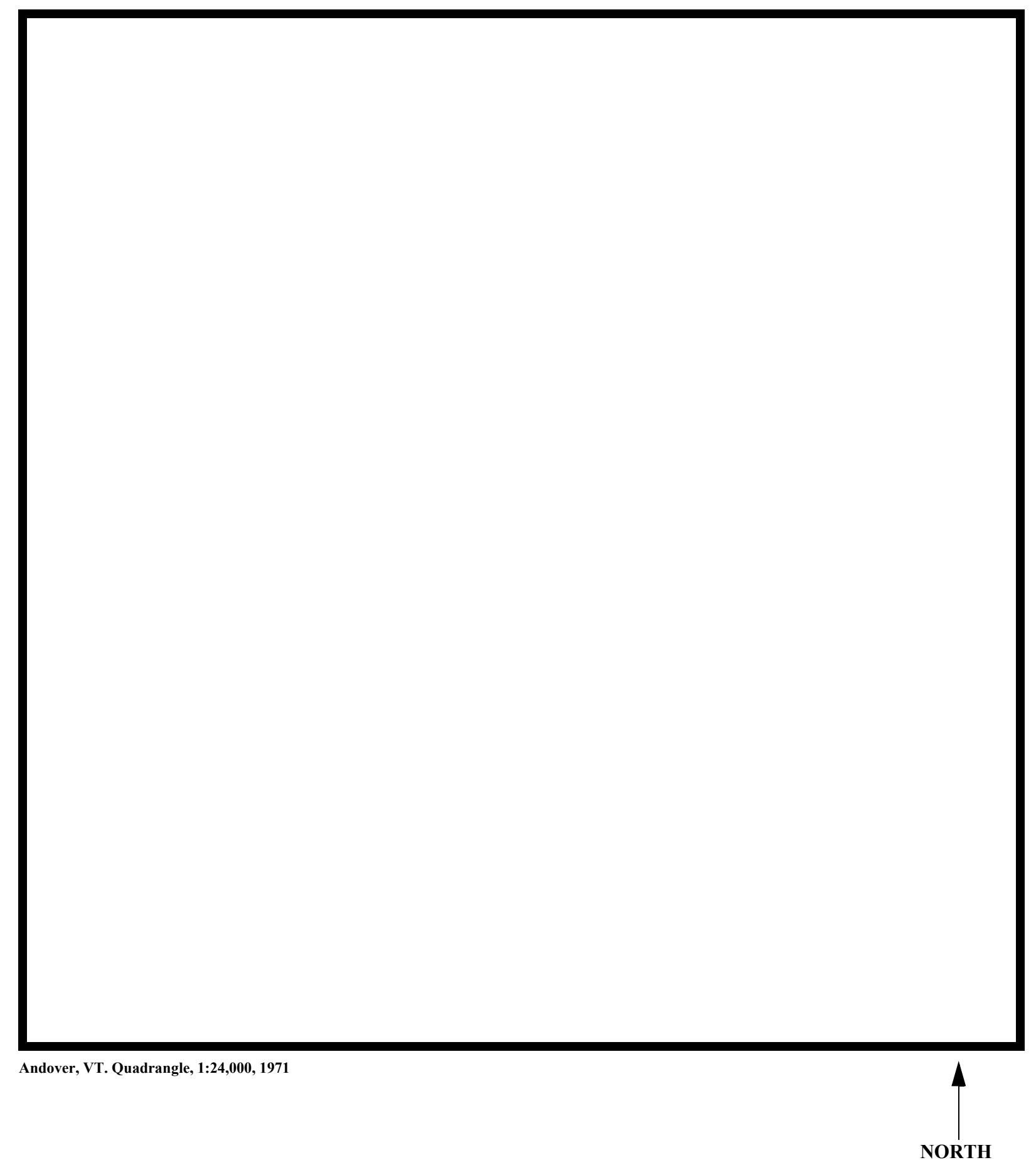

Figure 1. Location of study area on USGS 1:24,000 scale map. 
Figure 2. Location of study area on Vermont Agency of Transportation town highway map. 

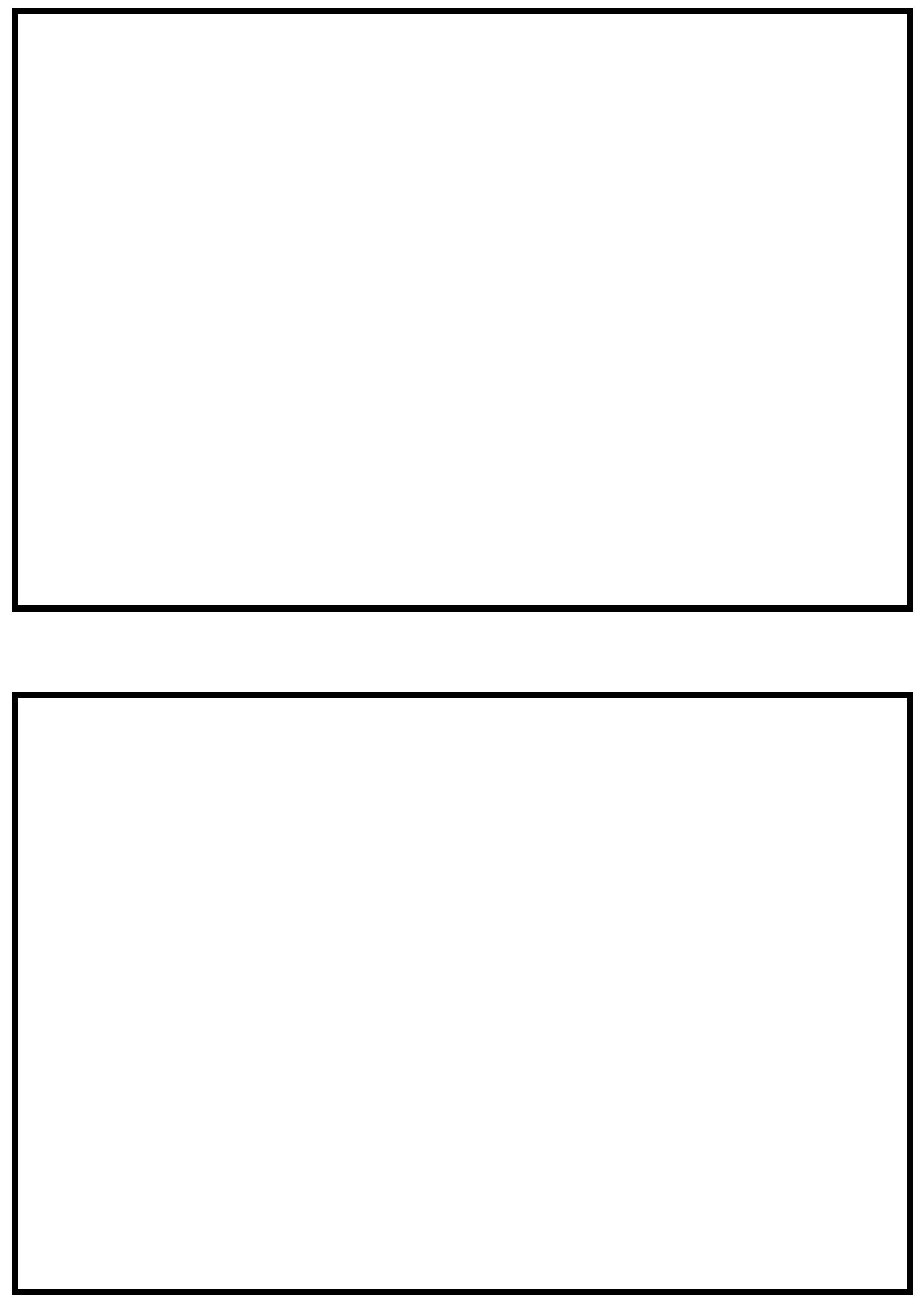

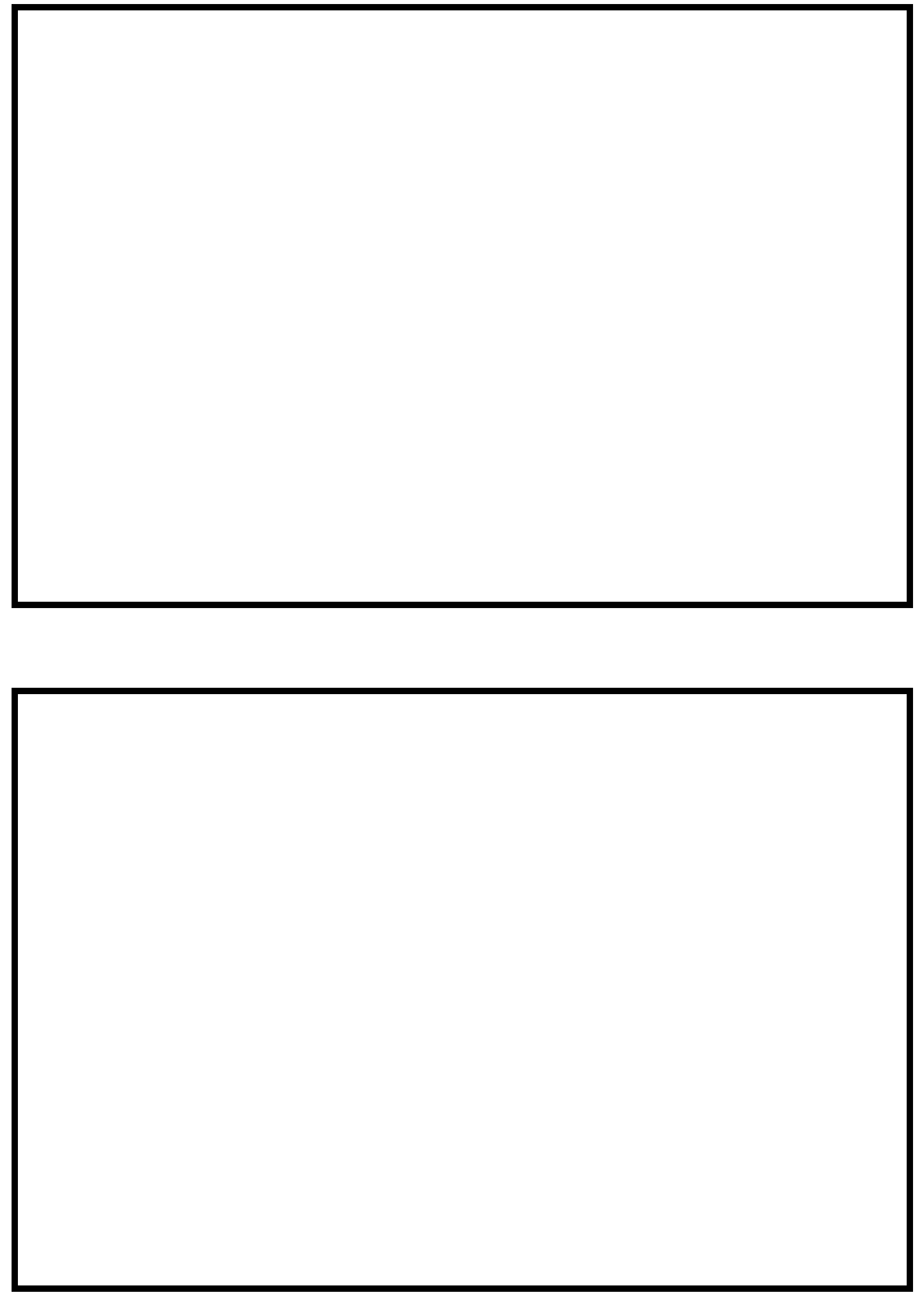


\section{Description of the Geomorphic Setting}

General topography The channel is located within a moderate relief valley with a narrow flood plain on the left.

Geomorphic conditions at bridge site: downstream (DS), upstream (US)

Date of inspection $\quad 09 / 09 / 96$

DS left: $\quad$ Steep channel bank to a narrow flood plain.

DS right: $\quad$ Confluence with the Middle Branch Williams River.

US left: $\quad$ Steep channel bank to a narrow flood plain.

US right: $\quad$ Steep channel bank to a moderately sloping overbank.

\section{Description of the Channel}

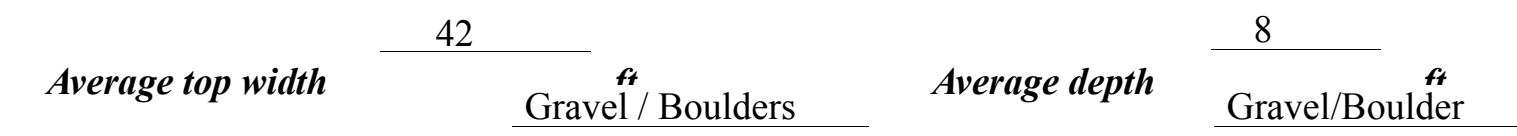

Predominant bed material

Bank material

Straight and stable

with semi-alluvial channel boundaries and a narrow flood plain on the left.

$09 / 09 / 96$

Vegetative co 1 Trees and brush on the immediate bank with pasture on the flood plain.

DS left: $\quad$ Brush and grass.

DS right: $\quad$ Trees and brush on the immediate bank with pasture on the flood plain.

US left: $\quad$ Trees and brush on the immediate bank with pasture on the overbank.

US right: $\quad$ Yes

Do banks appear stable? -

date of observation.

The assessment of

09/09/96 noted a point bar along the right bank upstream and along the left bank through the Describe any obstructions in channel and date of observation.

bridge. 


\title{
Hydrology
}

Drainage area $\stackrel{4.18}{\boldsymbol{m i}^{2}}$

Percentage of drainage area in physiographic provinces: (approximate)

Physiographic province/section

New England/Green Mountain
Percent of drainage area 100

\begin{abstract}
Is drainage area considered rural or urban?
Rural urbanization:

Describe any significant
\end{abstract}

Is there a USGS gage on the stream of interest? ${ }_{--}^{\text {No }}$
USGS gage description

USGS gage number

Gage drainage area $\mathrm{mi}^{2}$

No

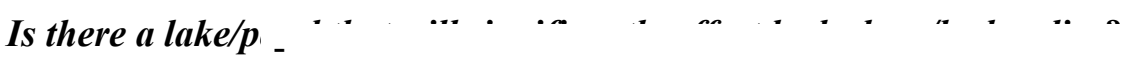

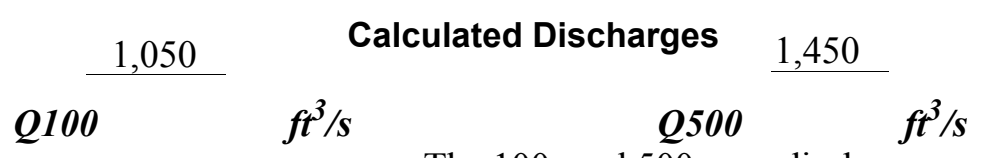

The 100- and 500-year discharges are based on a

drainage area relationship.[(4.2/3.9)exp 0.7] with bridge number 26 in Andover. Bridge number 26 crosses Lyman Brook upstream of this site and has flood frequency estimates available from the VTAOT database. The drainage area above bridge number 26 is 3.9 square miles. These values are within a range defined by several empirical flood frequency curves (Benson, 1962; Johnson and Tasker, 1974; FHWA, 1983; Potter, 1957a\&b; Talbot, 1887). 


\section{Description of the Water-Surface Profile Model (WSPRO) Analysis}

Datum for WSPRO analysis (USGS survey, sea level, VTAOT plans)

USGS survey

Datum tie between USGS survey and VTAOT plans

Subtract $53.0 \mathrm{ft}$ from the USGS

arbitrary survey datum to obtain VTAOT plans' datum.

Description of reference marks used to determine USGS datum. $\quad$ RM13 is a chiseled X on top of the upstream end of the right abutment (elev. $420.39 \mathrm{ft}$, arbitrary survey datum). RM14 is

a chiseled X on top of the downstream end of the left abutment (elev. $419.97 \mathrm{ft}$, arbitrary survey

datum).

Cross-Sections Used in WSPRO Analysis

\begin{tabular}{ccll}
\hline${ }^{1}$ Cross-section & $\begin{array}{c}\text { Section } \\
\text { Reference } \\
\text { Distance } \\
\text { (SRD) } \text { in feet }\end{array}$ & $\begin{array}{c}{ }^{2} \text { Cross-section } \\
\text { development }\end{array}$ & \multicolumn{1}{c}{ Comments } \\
\hline EXITX & -25 & 2 & $\begin{array}{l}\text { Modelled Exit section } \\
\text { (Templated from }\end{array}$ \\
EXTEM) & $\begin{array}{l}\text { Exit section as surveyed } \\
\text { (Used as a template) }\end{array}$ \\
FULLV & -5 & 1 & $\begin{array}{l}\text { Downstream Full-valley } \\
\text { section (Templated from } \\
\text { EXTEM) }\end{array}$ \\
DSBRG & 0 & 2 & $\begin{array}{l}\text { Bridge section } \\
\text { RDWAY }\end{array}$ \\
RPPRO & 13 & 1 & $\begin{array}{l}\text { Road Grade section } \\
\text { Modelled Approach sec- } \\
\text { tion (Templated from } \\
\text { APTEM) }\end{array}$ \\
& 51 & 1 & $\begin{array}{l}\text { Approach section as sur- } \\
\text { veyed (Used as a tem- } \\
\text { plate) }\end{array}$ \\
\hline
\end{tabular}

${ }^{1}$ For location of cross-sections see plan-view sketch included with Level I field form, Appendix E.

For more detail on how cross-sections were developed see WSPRO input file. 


\section{Data and Assumptions Used in WSPRO Model}

Hydraulic analyses of the reach were done by use of the Federal Highway Administration's WSPRO step-backwater computer program (Shearman and others, 1986, and Shearman, 1990). The analyses reported herein reflect conditions existing at the site at the time of the study. Furthermore, in the development of the model it was necessary to assume no accumulation of debris or ice at the site. Results of the hydraulic model are presented in the Bridge Hydraulic Summary, Appendix B, and figure 7.

Channel roughness factors (Manning's " $n$ ") used in the hydraulic model were estimated using field inspections at each cross section following the general guidelines described by Arcement and Schneider (1989). Final adjustments to the values were made during the modelling of the reach. Channel "n" values for the reach ranged from 0.045 to 0.065 , and overbank "n" values ranged from 0.025 to 0.055 .

Normal depth at the exit section (EXITX) was assumed as the starting water surface. This depth was computed by use of the slope-conveyance method outlined in the user's manual for WSPRO (Shearman, 1990). The slope used was $0.0278 \mathrm{ft} / \mathrm{ft}$ which was calculated from the surveyed thalweg points downstream of the bridge. Lyman Brook enters the Middle Branch of the Williams River just downstream of the bridge. The surveyed exit section (EXTEM) was moved along the exit channel slope $(0.0278 \mathrm{ft} / \mathrm{ft})$ to establish the modelled exit section (EXITX). Normal depth was assumed at the templated exit section (EXITX) based on the assumption that Lyman Brook will rise prior to or with the Middle Branch of the Williams River.

The surveyed approach section (APTEM) was moved along the approach channel slope $(0.021 \mathrm{ft} / \mathrm{ft})$ to establish the modelled approach section (APPRO), one bridge length upstream of the upstream face as recommended by Shearman and others (1986). This location also provides a consistent method for determining scour variables.

For the 100-year and incipient-overtopping discharge, WSPRO assumes critical depth at the bridge section. Supercritical models were developed for these discharges. After analyzing both the supercritical and subcritical profiles for each discharge, it can be determined that the water surface profile does pass through critical depth within the bridge opening. Thus, the assumptions of critical depth at the bridge are satisfactory solutions. 


\section{Bridge Hydraulics Summary}

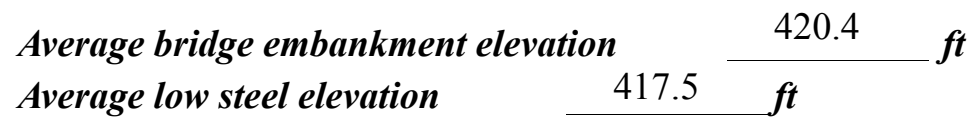

$$
\text { 100-year discharge } \quad 1,050 \quad \mathrm{ft}^{3} / \mathrm{s}
$$

Water-surface elevation in bridge opening $\quad 414.0 \quad f t$

Road overtopping? ___ No Discharge over road ___ -- $\mathrm{ft}^{3} / \mathrm{s}$

Area of flow in bridge opening $\quad 90 \quad \mathrm{ft}^{2}$

Average velocity in bridge opening $11.7 \mathrm{ft} / \mathrm{s}$

$\begin{array}{llll}\text { Maximum WSPRO tube velocity at bridge } & 14.4 \mathrm{ft} / \mathrm{s}\end{array}$

Water-surface elevation at Approach section with bridge 416.6

Water-surface elevation at Approach section without bridge $\quad \overline{4} 4.9$

Amount of backwater caused by bridge $\quad 1.7 \quad$ it

500-year discharge $\quad 1,450 \quad \mathrm{ft}^{3} / \mathrm{s}$

Water-surface elevation in bridge opening $\quad 417.5 \mathrm{ft}$

Road overtopping? ___ Yes Discharge over road __ $163 \mathrm{ft}^{3} / \mathrm{s}$

$\begin{array}{llll}\text { Area of flow in bridge opening } & 164 & \boldsymbol{f t}^{2} & \\ \text { Average velocity in bridge opening } & & 8.0 \quad \mathrm{ft} / \mathrm{s}\end{array}$

Maximum WSPRO tube velocity at bridge 11.2 , $s$

Water-surface elevation at Approach section with bridge 419.0

Water-surface elevation at Approach section without bridge $\quad 417.1$

Amount of backwater caused by bridge $1.9, t$

Incipient overtopping discharge $\quad 1,200 \mathrm{ft}^{3} / \mathrm{s}$

Water-surface elevation in bridge opening $414.4 \quad t$

Area of flow in bridge opening $\quad 98 \quad \mathrm{ft}^{2}$

Average velocity in bridge opening $\quad 12.2 \quad \mathrm{ft} / \mathrm{s}$

Maximum WSPRO tube velocity at bridge $15.1 \mathrm{ft} / \mathrm{s}$

Water-surface elevation at Approach section with bridge

Water-surface elevation at Approach section without bridge

417.5

Amount of backwater caused by bridge $\quad 2.2$, $t$ 


\section{Scour Analysis Summary}

\section{Special Conditions or Assumptions Made in Scour Analysis}

Scour depths were computed using the general guidelines described in Hydraulic Engineering Circular 18 (Richardson and others, 1995). Scour depths were calculated assuming an infinite depth of erosive material and a homogeneous particle-size distribution. The results of the scour analysis are presented in tables 1 and 2 and a graph of the scour depths is presented in figure 8 .

Contraction scour for the 100-year and incipient-overtopping discharges were computed by use of the clear-water contraction scour equation (Richardson and others, 1995, p. 32, equation 20). At this site, the 500-year discharge resulted in unsubmerged orifice flow. Contraction scour at bridges with orifice flow is best estimated by use of the Chang pressureflow scour equation (oral communication, J. Sterling Jones, October 4, 1996). Thus, contraction scour was computed by use of the Chang equation (Richardson and others, 1995, p. 145-146). Results of this analysis are presented in figure 8 and tables 1 and 2. The streambed armoring depths computed suggest that armoring will not limit the depth of contraction scour.

Additional estimates of contraction scour also were computed by use of Laursen's clear-water scour equation (Richardson and others, 1995, p. 32, equation 20) and the results are presented in Appendix F. Furthermore, for those discharges resulting in unsubmerged orifice flow, contraction scour was computed by substituting alternative estimates for the depth of flow in the bridge at the downstream face in the Chang equation and Laursen's clear-water equation. Contraction scour results with respect to these substitutions also are provided in Appendix F.

Abutment scour for the right abutment was computed by use of the Froehlich equation (Richardson and others, 1995, p. 48, equation 28). Variables for the Froehlich equation include the Froude number of the flow approaching the embankments, the length of the embankment blocking flow, and the depth of flow approaching the embankment less any roadway overtopping.

Scour at the left abutment was computed by use of the HIRE equation (Richardson and others, 1995, p. 49, equation 29) because the HIRE equation is recommended when the length to depth ratio of the embankment blocking flow exceeds 25 . The variables used by the HIRE abutment-scour equation are defined the same as those defined for the Froehlich abutment-scour equation. 


\section{Scour Results}

100-yr discharge 500-yr discharge

Incipient

overtopping

Contraction scour:

(Scour depths in feet)

Main channel

Live-bed scour

Clear-water scour

Depth to armoring

Left overbank

Right overbank

Local scour:

Abutment scour

Left abutment

1.2

7.5

3.6

Right abutment

Pier scour

Pier 1

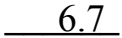

5.2

6.2

Pier 2

Pier 3

Abutments:

Left abutment

Right abutment

Piers:

Pier 1

Pier 2

\section{Riprap Sizing}

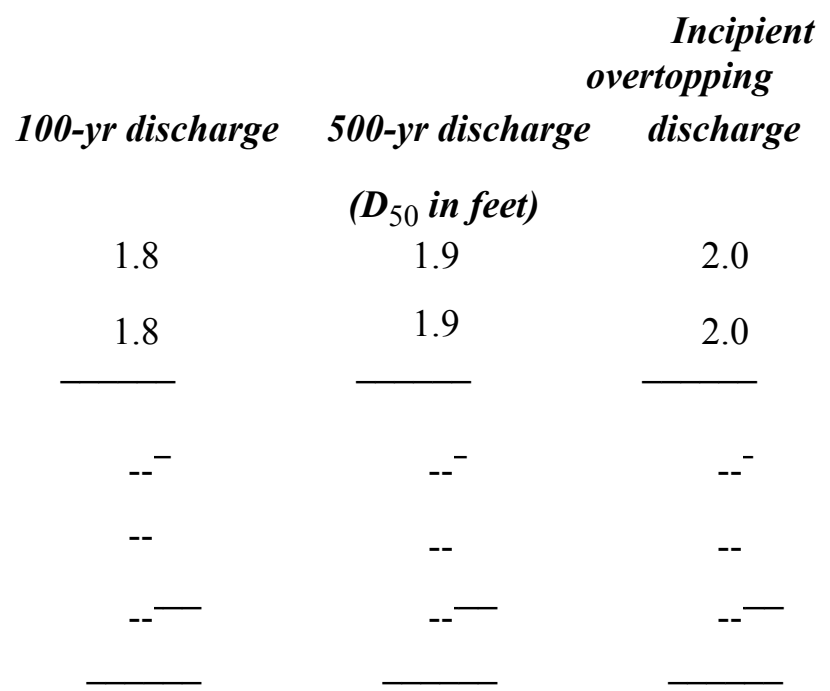




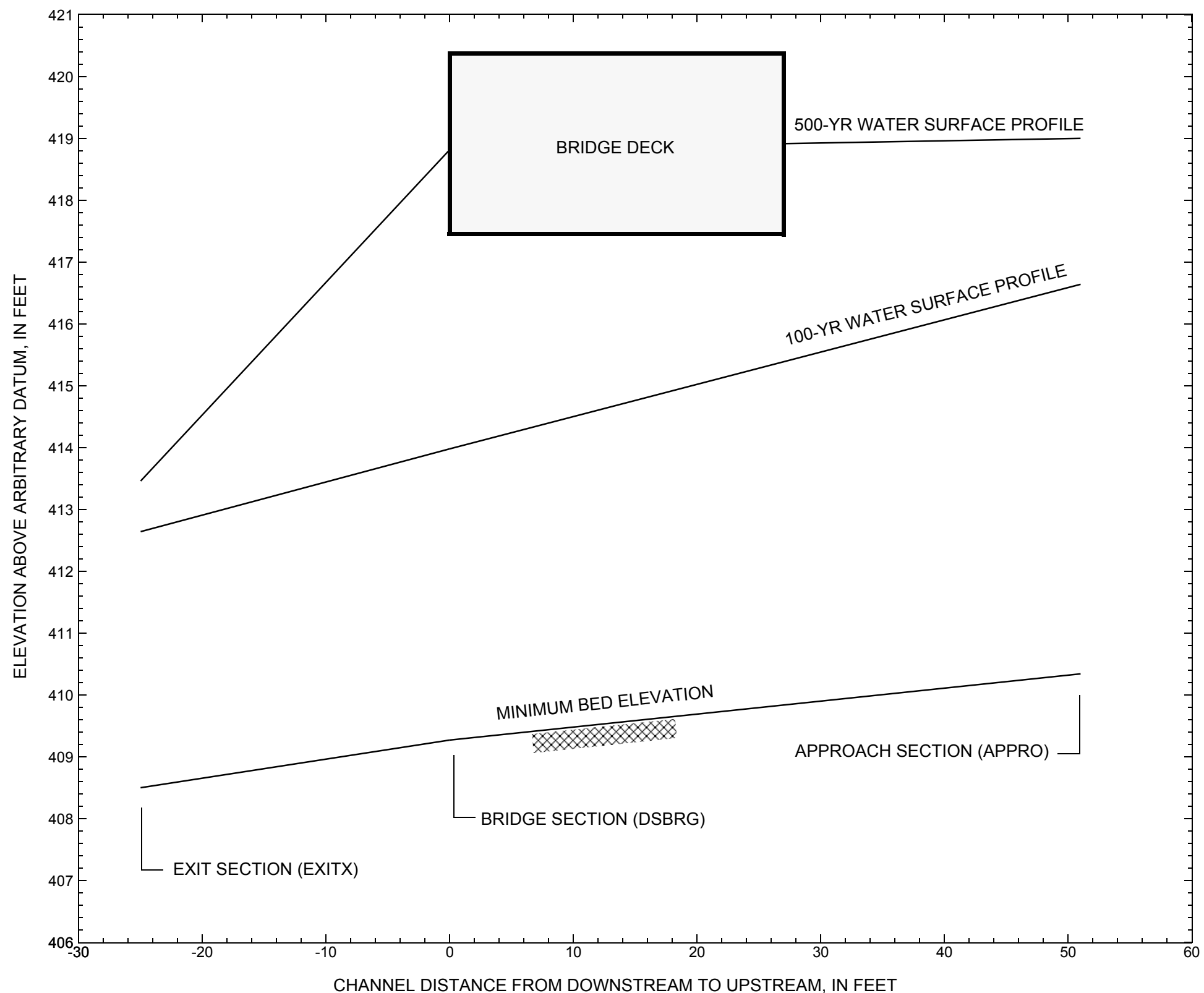

Figure 7. Water-surface profiles for the 100- and 500-yr discharges at structure ANDOVT00110040 on State Route 11, crossing Lyman Brook, Andover, Vermont. 


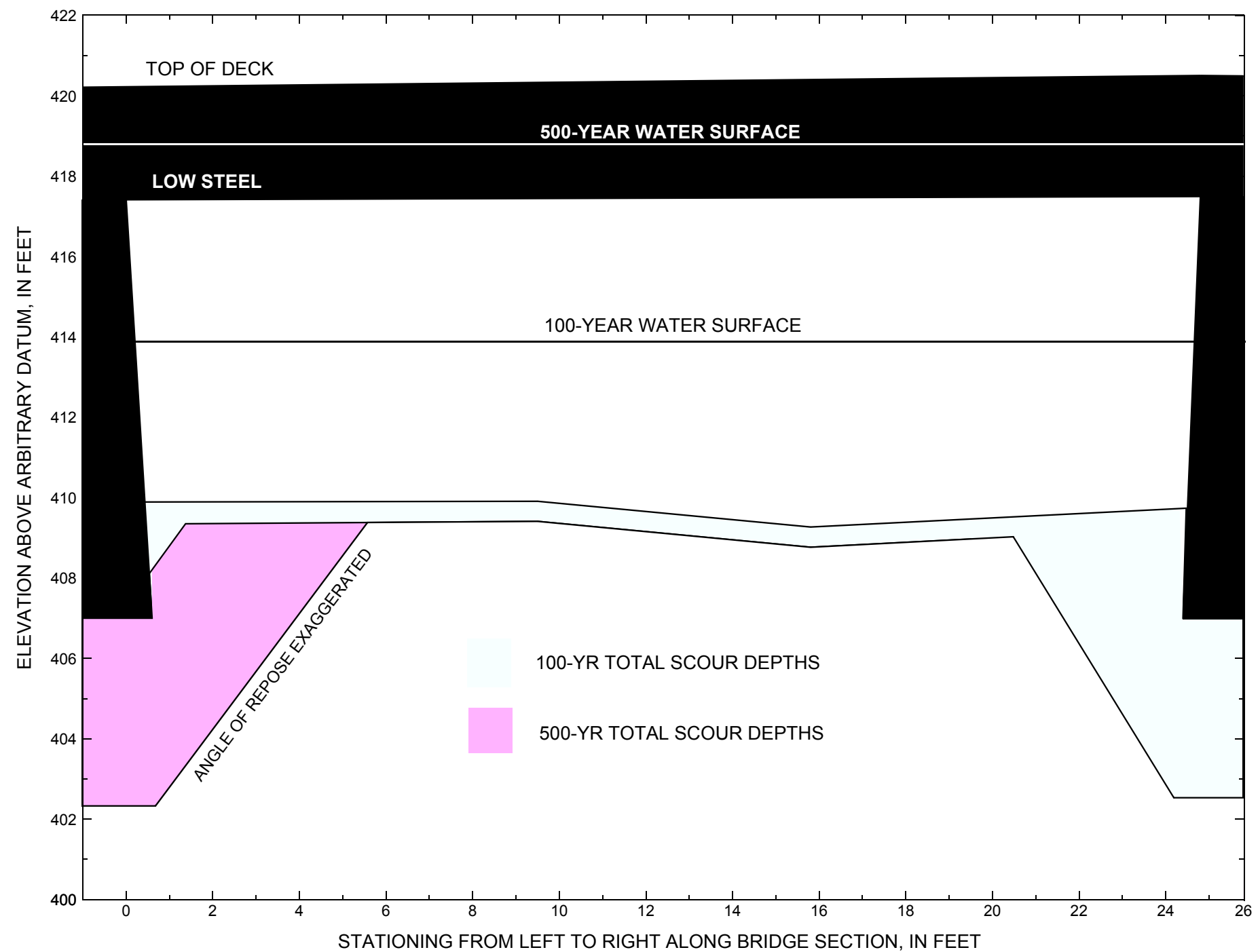

Figure 8. Scour elevations for the 100-yr and 500-yr discharges at structure ANDOVT00110040 on State Route 11, crossing Lyman Brook, Andover, Vermont. 
Table 1. Remaining footing/pile depth at abutments for the 100-year discharge at structure ANDOVT00110040 on State Route 11, crossing Lyman Brook, Andover, Vermont. [VTAOT, Vermont Agency of Transportation; --,no data]

\begin{tabular}{|c|c|c|c|c|c|c|c|c|c|c|c|}
\hline Description & Station $^{1}$ & $\begin{array}{c}\text { VTAOT } \\
\text { minimum } \\
\text { bridge seat } \\
\text { elevation } \\
\text { (feet) }\end{array}$ & $\begin{array}{c}\text { Surveyed } \\
\text { minimum } \\
\text { low-chord } \\
\text { elevation } \\
\text { (feet) }\end{array}$ & $\begin{array}{c}\text { Bottom of } \\
\text { footing } \\
\text { elevation } \\
\text { (feet) }\end{array}$ & $\begin{array}{c}\text { Channel } \\
\text { elevation at } \\
\text { abutment/ } \\
\text { pier }^{2} \\
\text { (feet) }\end{array}$ & $\begin{array}{l}\text { Contraction } \\
\text { scour depth } \\
\quad \text { (feet) }\end{array}$ & $\begin{array}{l}\text { Abutment } \\
\text { scour } \\
\text { depth } \\
\text { (feet) }\end{array}$ & $\begin{array}{l}\text { Pier scour } \\
\text { depth } \\
\text { (feet) }\end{array}$ & $\begin{array}{l}\text { Depth of } \\
\text { total scour } \\
\text { (feet) }\end{array}$ & $\begin{array}{c}\text { Elevation of } \\
\text { scour }^{2} \\
\text { (feet) }\end{array}$ & $\begin{array}{c}\text { Remaining } \\
\text { footing/pile } \\
\text { depth } \\
\text { (feet) }\end{array}$ \\
\hline \multicolumn{12}{|c|}{100 -yr. discharge is 1,050 cubic-feet per second } \\
\hline Left abutment & 0.0 & 367.0 & 417.4 & 407.0 & 409.8 & 0.5 & 1.2 & -- & 1.7 & 408.1 & 1.1 \\
\hline Right abutment & 24.8 & 367.0 & 417.5 & 407.0 & 409.7 & 0.5 & 6.7 & -- & 7.2 & 402.5 & -4.5 \\
\hline
\end{tabular}

1.Measured along the face of the most constricting side of the bridge

2.Arbitrary datum for this study.

Table 2. Remaining footing/pile depth at abutments for the 500-year discharge at structure ANDOVT00110040 on State Route 11, crossing Lyman Brook, Andover, Vermont. [VTAOT, Vermont Agency of Transportation; --, no data]

\begin{tabular}{|c|c|c|c|c|c|c|c|c|c|c|c|}
\hline Description & Station $^{1}$ & $\begin{array}{l}\text { VTAOT } \\
\text { minimum } \\
\text { bridge seat } \\
\text { elevation } \\
\text { (feet) }\end{array}$ & $\begin{array}{l}\text { Surveyed } \\
\text { minimum } \\
\text { low-chord } \\
\text { elevation } \\
\text { (feet) }\end{array}$ & $\begin{array}{c}\text { Bottom of } \\
\text { footing } \\
\text { elevation } \\
\text { (feet) }\end{array}$ & $\begin{array}{c}\text { Channel } \\
\text { elevation at } \\
\text { abutment/ } \\
\text { pier }^{2} \\
\text { (feet) }\end{array}$ & $\begin{array}{l}\text { Contraction } \\
\text { scour depth } \\
\text { (feet) }\end{array}$ & $\begin{array}{l}\text { Abutment } \\
\text { scour } \\
\text { depth } \\
\text { (feet) }\end{array}$ & $\begin{array}{l}\text { Pier } \\
\text { scour } \\
\text { depth } \\
\text { (feet) }\end{array}$ & $\begin{array}{l}\text { Depth of } \\
\text { total scour } \\
\text { (feet) }\end{array}$ & $\begin{array}{c}\text { Elevation of } \\
\text { scour }^{2} \\
\text { (feet) }\end{array}$ & $\begin{array}{c}\text { Remaining } \\
\text { footing/pile } \\
\text { depth } \\
\text { (feet) }\end{array}$ \\
\hline \multicolumn{12}{|c|}{ 500-yr. discharge is 1,450 cubic-feet per second } \\
\hline Left abutment & 0.0 & 367.0 & 417.4 & 407.0 & 409.8 & 0.0 & 7.5 & -- & 7.5 & 402.3 & -4.7 \\
\hline Right abutment & 24.8 & 367.0 & 417.5 & 407.0 & 409.7 & 0.0 & 5.2 & -- & 5.2 & 404.5 & -2.5 \\
\hline
\end{tabular}

1.Measured along the face of the most constricting side of the bridge.

2.Arbitrary datum for this study. 


\section{SELECTED REFERENCES}

Arcement, G.J., Jr., and Schneider, V.R., 1989, Guide for selecting Manning's roughness coefficients for natural channels and flood plains: U.S. Geological Survey Water-Supply Paper 2339, 38 p.

Barnes, H.H., Jr., 1967, Roughness characteristics of natural channels: U.S. Geological Survey Water-Supply Paper 1849,213 p.

Benson, M. A., 1962, Factors Influencing the Occurrence of Floods in a Humid Region of Diverse Terrain: U.S. Geological Survey WaterSupply Paper 1580-B, 64 p.

Brown, S.A. and Clyde, E.S., 1989, Design of riprap revetment: Federal Highway Administration Hydraulic Engineering Circular No. 11, Publication FHWA-IP-89-016, 156 p.

Federal Highway Administration, 1983, Runoff estimates for small watersheds and development of sound design: Federal Highway Administration Report FHWA-RD-77-158.

Federal Highway Administration, 1993, Stream Stability and Scour at Highway Bridges: Participant Workbook: Federal Highway Administration Report FHWA-HI-91-011.

Froehlich, D.C., 1989, Local scour at bridge abutments in Ports, M.A., ed., Hydraulic Engineering--Proceedings of the 1989 National Conference on Hydraulic Engineering: New York, American Society of Civil Engineers, p. 13-18.

Hayes, D.C.,1993, Site selection and collection of bridge-scour data in Delaware, Maryland, and Virginia: U.S. Geological Survey WaterResources Investigation Report 93-4017, 23 p.

Interagency Advisory Committee on Water Data, 1982, Guidelines for determining flood flow frequency: U.S. Geological Survey, Bulletin 17B of the Hydrology Subcommittee, 190 p.

Johnson, C.G. and Tasker, G.D.,1974, Progress report on flood magnitude and frequency of Vermont streams: U.S. Geological Survey OpenFile Report 74-130, 37 p.

Lagasse, P.F., Schall, J.D., Johnson, F., Richardson, E.V., Chang, F., 1995, Stream Stability at Highway Structures: Federal Highway Administration Hydraulic Engineering Circular No. 20, Publication FHWA-IP-90-014, 144 p.

Laursen, E.M., 1960, Scour at bridge crossings: Journal of the Hydraulics Division, American Society of Civil Engineers, v. 86, no. HY2, p. 39-53.

Potter, W. D., 1957a, Peak rates of runoff in the Adirondack, White Mountains, and Maine woods area, Bureau of Public Roads

Potter, W. D., 1957b, Peak rates of runoff in the New England Hill and Lowland area, Bureau of Public Roads

Richardson, E.V. and Davis, S.R., 1995, Evaluating scour at bridges: Federal Highway Administration Hydraulic Engineering Circular No. 18, Publication FHWA-IP-90-017, 204 p.

Richardson, E.V., Simons, D.B., and Julien, P.Y., 1990, Highways in the river environment: Federal Highway Administration Publication FHWA-HI-90-016.

Ritter, D.F., 1984, Process Geomorphology: W.C. Brown Co., Debuque, Iowa, 603 p.

Shearman, J.O., 1990, User's manual for WSPRO--a computer model for water surface profile computations: Federal Highway Administration Publication FHWA-IP-89-027, 187 p.

Shearman, J.O., Kirby, W.H., Schneider, V.R., and Flippo, H.N., 1986, Bridge waterways analysis model; research report: Federal Highway Administration Publication FHWA-RD-86-108, 112 p.

Talbot, A.N., 1887, The determination of water-way for bridges and culverts.

U.S. Department of Transportation, 1993, Stream stability and scour at highway bridges, Participant Workbook: Federal Highway Administration Publication FHWA HI-91-011.

U.S. Geological Survey, 1971, Andover, Vermont 7.5 Minute Series quadrangle map: U.S. Geological Survey Topographic Maps, Scale $1: 24,000$. 


\section{APPENDIX A: \\ WSPRO INPUT FILE}




\section{WSPRO INPUT FILE}

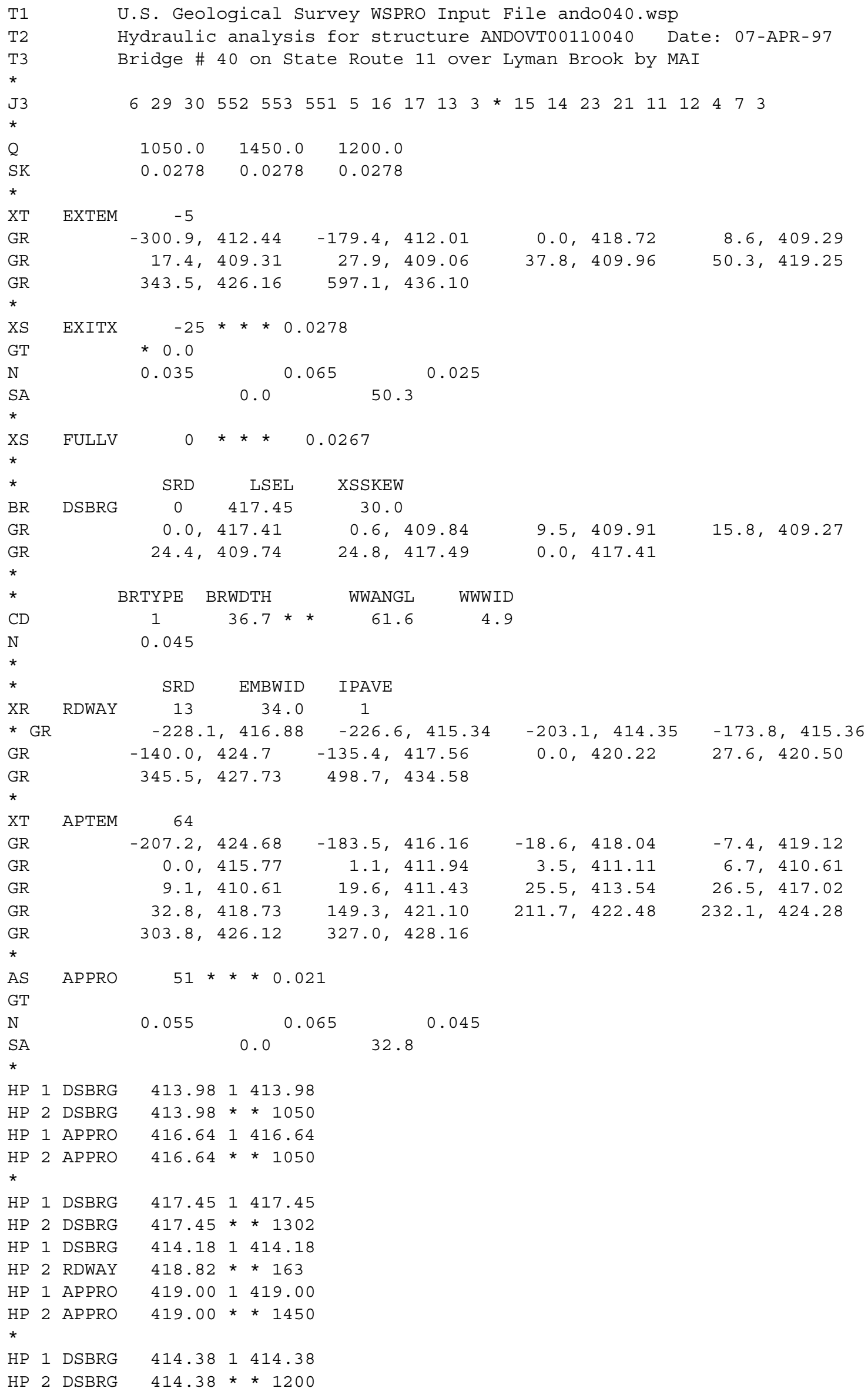




\section{APPENDIX B: \\ WSPRO OUTPUT FILE}




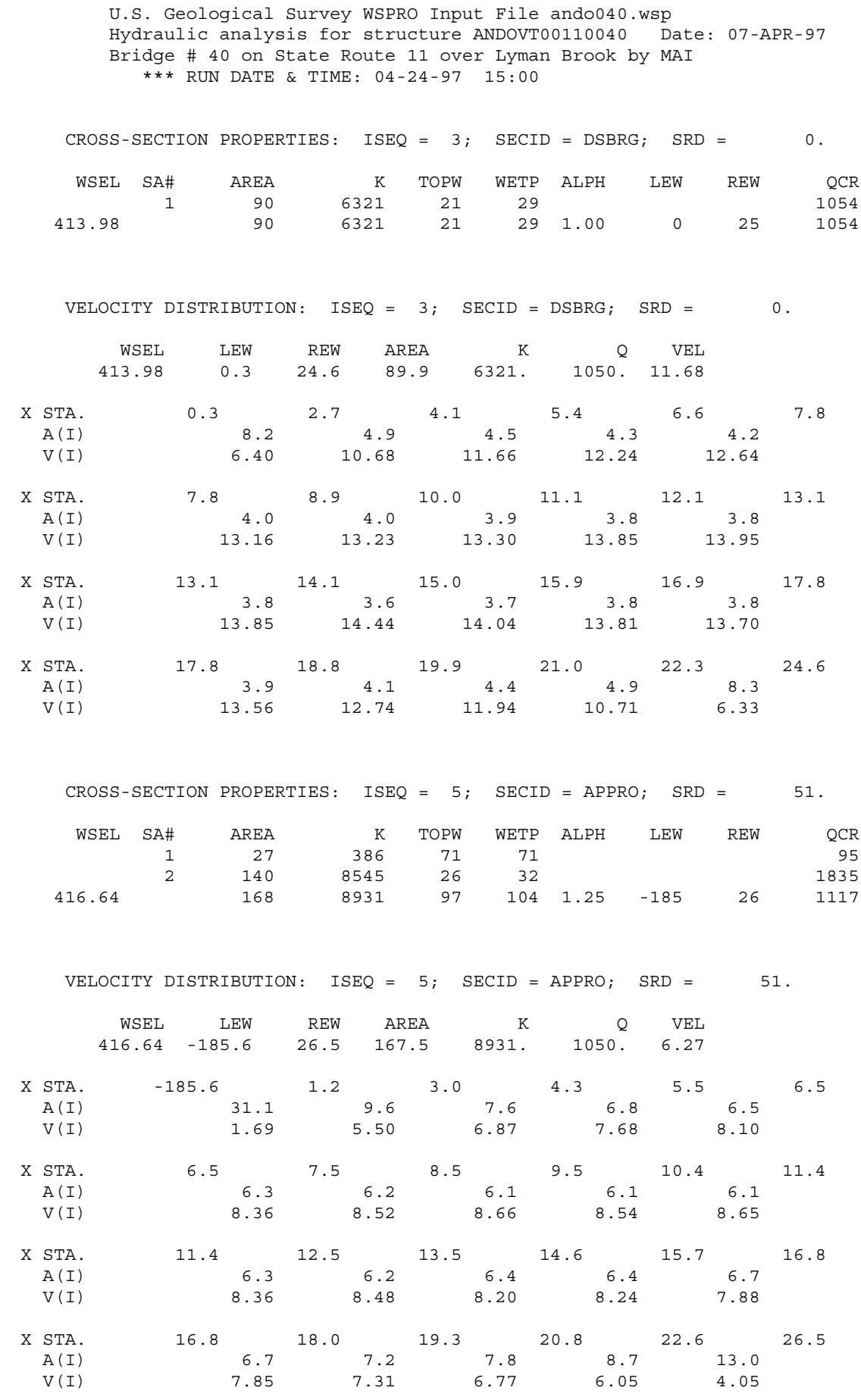




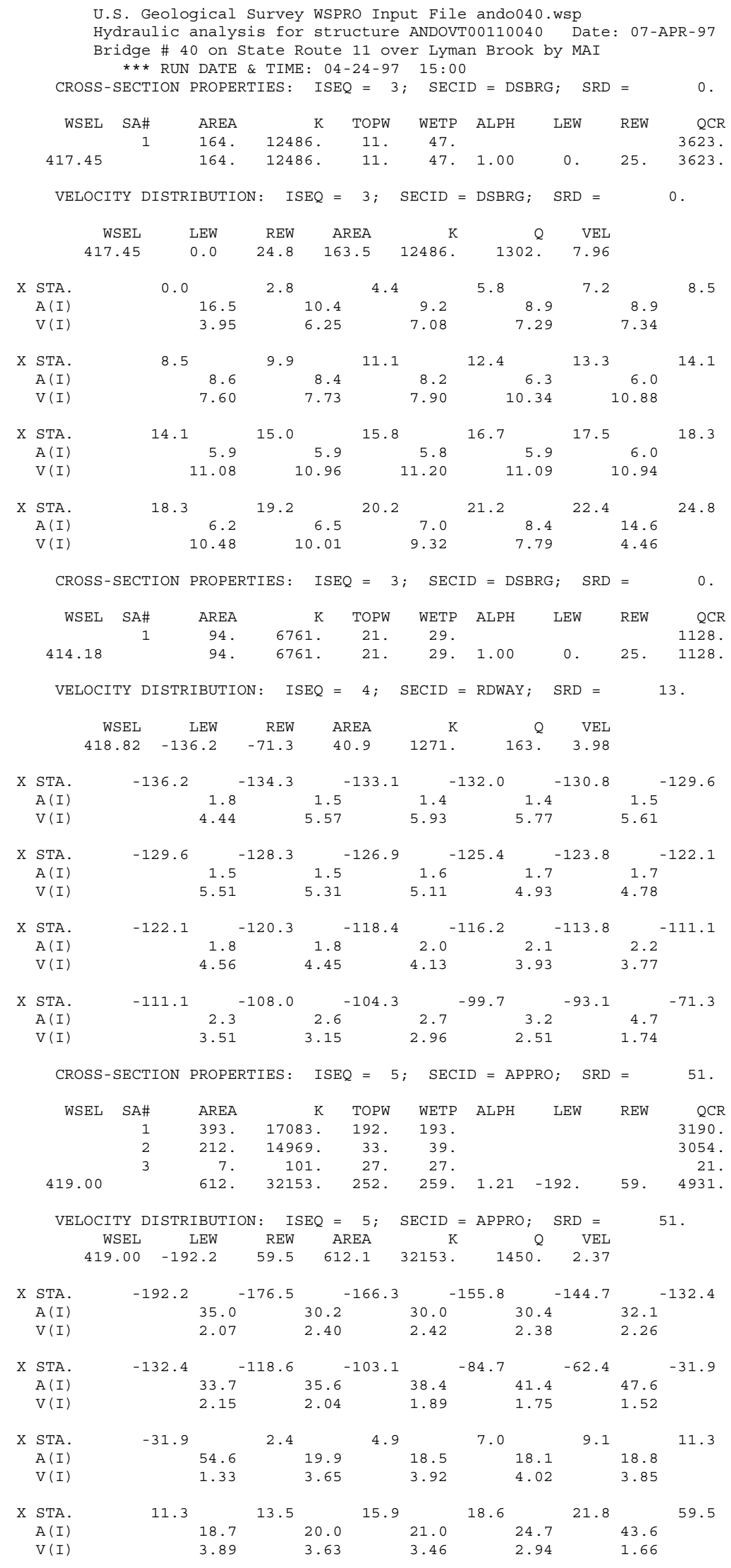


WSPRO OUTPUT FILE (continued)

Geological Survey WSPRO Input File ando040.wsp

Hydraulic analysis for structure ANDOVT00110040 Date: 07-APR-97 Bridge \# 40 on State Route 11 over Lyman Brook by MAI

*** RUN DATE \& TIME: 04-24-97 15:00

CROSS-SECTION PROPERTIES: ISEQ $=3 ;$ SECID $=$ DSBRG $; \quad$ SRD $=\quad 0$.

\begin{tabular}{|c|c|c|c|c|c|c|c|c|c|}
\hline WSEL & SA\# & AREA & $\mathrm{K}$ & TOPW & WETP & ALPH & LEW & REW & QCR \\
\hline & 1 & 98. & 7209 . & 21. & 30. & & & & 1204 \\
\hline 114.38 & & 98. & 7209 . & 21. & 30. & 1.00 & 0 . & 25. & \\
\hline
\end{tabular}

\begin{tabular}{|c|c|c|c|c|c|c|c|c|c|}
\hline & & WSEL & LEW & REW & AREA & K & Q & VEL & \\
\hline & & 414.38 & 0.2 & 24.6 & 98.4 & 7209. & 1200. & 12.20 & \\
\hline \multirow[t]{3}{*}{$\mathrm{X}$} & STA. & & 0.2 & 2.7 & & & 5.4 & 6.6 & 7.8 \\
\hline & $A(I)$ & & 9.1 & 5.5 & & 4.9 & 4.7 & 4.5 & \\
\hline & $V(I)$ & & 6.58 & 10.87 & & 12.27 & 12.88 & 13.30 & \\
\hline \multirow[t]{3}{*}{ X } & STA. & & 7.8 & 8.9 & 10 & & 11.0 & 12.1 & 13.1 \\
\hline & $A(I)$ & & 4.3 & 4.3 & & 4.2 & 4.1 & 4.1 & \\
\hline & $V(I)$ & & 13.84 & 13.92 & & 14.36 & 14.48 & 14.62 & \\
\hline \multirow[t]{3}{*}{$\mathrm{X}$} & STA. & & 13.1 & 14.0 & 14 & & 15.9 & 16.8 & 17.8 \\
\hline & $A(I)$ & & 4.0 & 4.1 & & 4.0 & 4.1 & 4.2 & \\
\hline & $V(I)$ & & 15.06 & 14.77 & & 14.84 & 14.57 & 14.44 & \\
\hline & STA. & & 17.8 & 18.8 & 19 & & 21.0 & 22.3 & 24.6 \\
\hline & $A(I)$ & & 4.3 & 4.5 & & 4.8 & 5.5 & 9.1 & \\
\hline & $V(I)$ & & 13.90 & 13.35 & & 12.50 & 10.84 & 6.61 & \\
\hline
\end{tabular}

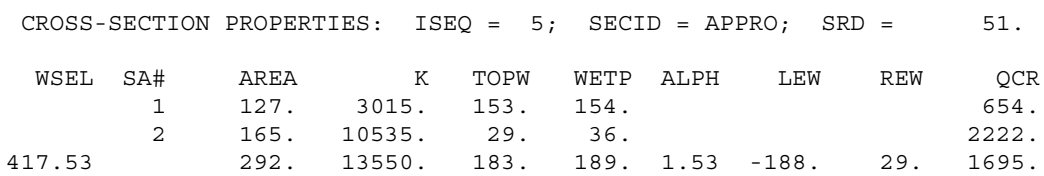

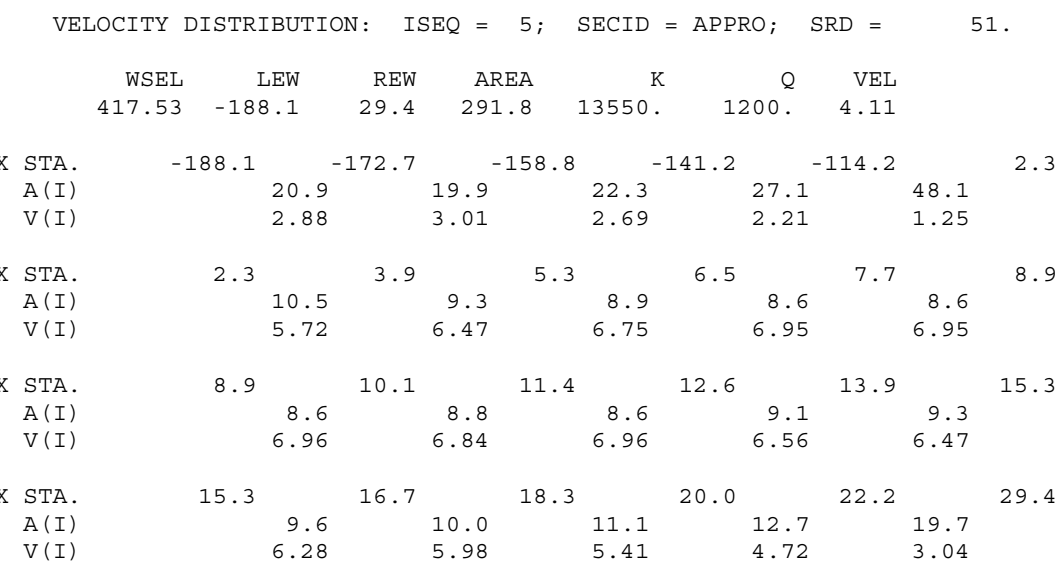


WSPRO OUTPUT FILE (continued)

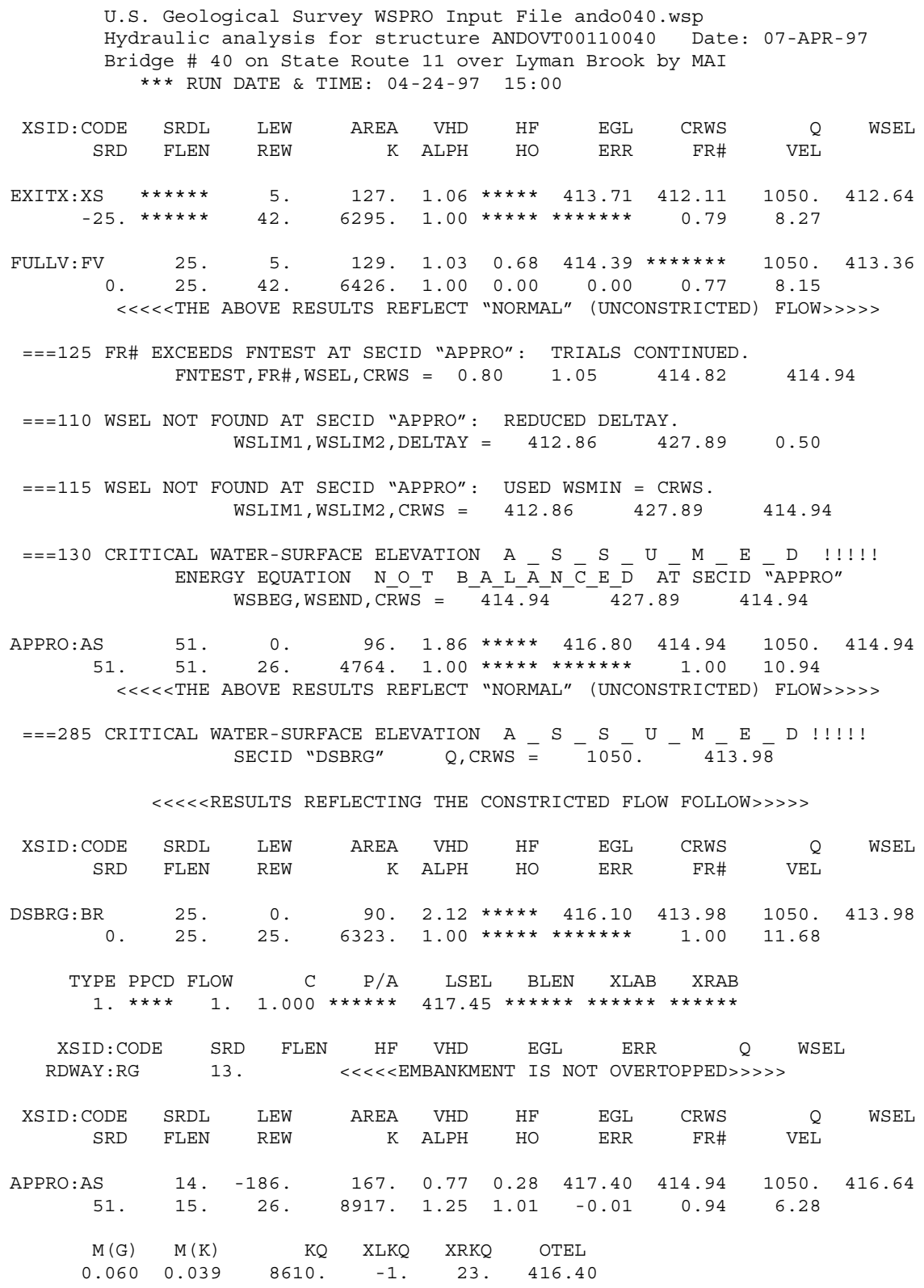

FIRST USER DEFINED TABLE.

\begin{tabular}{|c|c|c|c|c|c|c|c|c|}
\hline XSID : CODE & SRD & LEW & REW & $Q$ & $\mathrm{~K}$ & AREA & VEL & WSEL \\
\hline EXITX:XS & -25 & 5 . & 42 . & 1050. & 6295. & 127. & 8.27 & 412.64 \\
\hline FULLV : FV & 0 . & 5. & 42. & 1050. & 6426. & 129. & 8.15 & 413.36 \\
\hline DSBRG : BR & 0 . & 0 . & 25 . & 1050. & 6323. & 90. & 11.68 & 413.98 \\
\hline RDWAY : RG & \multicolumn{3}{|c|}{ 13. $* * \star * \star * \star * \star * * * \star * * *$} & \multicolumn{3}{|c|}{ 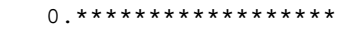 } & \multicolumn{2}{|c|}{$1.00 * * * * * * * *$} \\
\hline APPRO : AS & 51. & -186 & 26. & 1050. & 8917. & 167 & 6.28 & 416.64 \\
\hline XSID : CODE & XLKQ & XRKQ & & & & & & \\
\hline APPRO : AS & -1 & 23 . & 861 & & & & & \\
\hline
\end{tabular}

SECOND USER DEFINED TABLE.

\begin{tabular}{|c|c|c|c|c|c|c|c|c|c|}
\hline XSID : CODE & CRWS & FR\# & YMIN & YMAX & $\mathrm{HF}$ & $\mathrm{HO}$ & VHD & EGL & SEL \\
\hline EXITX:XS & 412.11 & .79 & 08.50 & 435.54 * & 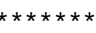 & $\star \star *$ & 1.06 & 13.71 & 412.64 \\
\hline FULLV & 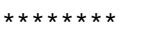 & 77 & 409.17 & 436.21 & 0.68 & 0.00 & 1.03 & 39 & 413.36 \\
\hline DSB & 413.98 & 1.00 & 409.27 & 417.49 ** & $\star \star \star \star \star * *$ & $* \star \star \star \star *$ & 2.12 & 416.10 & 413.98 \\
\hline DWAY : RG & 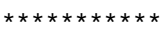 & $\star \star \star \star \star \star *$ & 417.56 & $434.58 * *$ & $\star * * * *$ & $\mathrm{An} \mathrm{n}$ & $\star \star \star \star \star ~$ & $\star \star \star *$ & 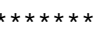 \\
\hline$A P P R O: A S$ & 414.94 & 0.94 & 410.34 & 427.89 & 0.28 & 1.01 & 0.77 & 417.40 & 416.64 \\
\hline
\end{tabular}


WSPRO OUTPUT FILE (continued)

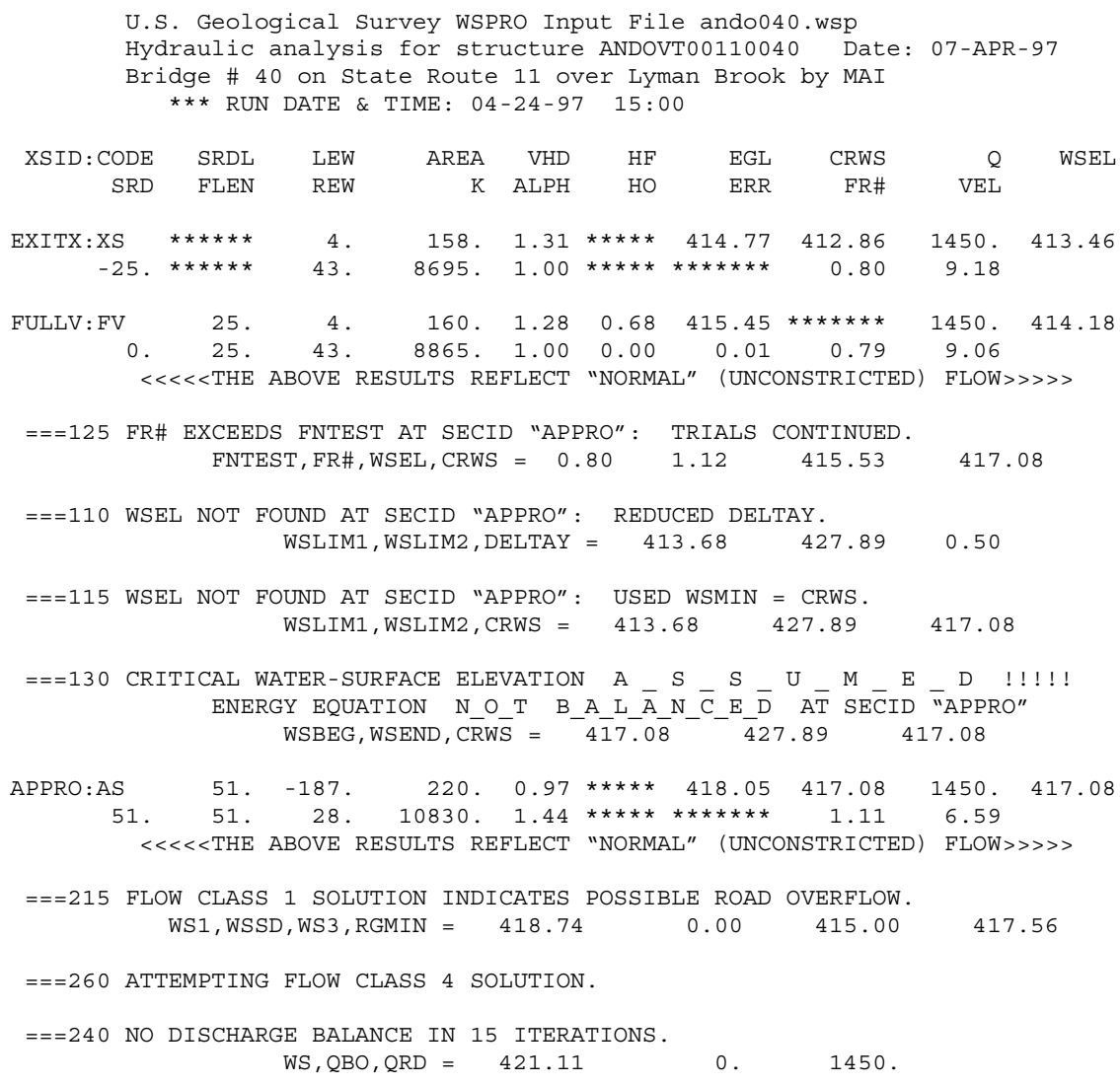

FIRST USER DEFINED TABLE.

$\begin{array}{lrrrrrrrr}\text { XSID : CODE } & \text { SRD } & \text { LEW } & \text { REW } & Q & \text { K } & \text { AREA } & \text { VEL } & \text { WSEL } \\ \text { EXITX : XS } & -25 . & 4 . & 43 . & 1450 . & 8695 . & 158 . & 9.18 & 413.46 \\ \text { FULLV : FV } & 0 . & 4 . & 43 . & 1450 . & 8865 . & 160 . & 9.06 & 414.18 \\ \text { DSBRG : BR } & 0 . & 0 . & 25 . & 1302 . & 12486 . & 164 . & 7.96 & 417.45 \\ \text { RDWAY : RG } & 13 . * * * * * * & 163 . & 163 . * * * * * * * & 0 . & 1.00 & 418.82 \\ \text { APPRO : AS } & 51 . & -192 . & 59 . & 1450 . & 32139 . & 612 . & 2.37 & 419.00\end{array}$

SECOND USER DEFINED TABLE.

$\begin{array}{lcrrrrrrrr}\text { XSID:CODE } & \text { CRWS } & \text { FR\# } & \text { YMIN } & \text { YMAX } & \text { HF } & \text { HO } & \text { VHD } & \text { EGL } & \text { WSEL } \\ \text { EXITX:XS } & 412.86 & 0.80 & 408.50 & 435.54 * * * * * * * * * * * & 1.31 & 414.77 & 413.46 \\ \text { FULLV:FV } & * * * * * * * & 0.79 & 409.17 & 436.21 & 0.68 & 0.00 & 1.28 & 415.45 & 414.18 \\ \text { DSBRG:BR } & 414.64 & 0.55 & 409.27 & 417.49 * * * * * * * * * * * & 0.99 & 418.44 & 417.45 \\ \text { RDWAY: RG } & * * * * * * * * * * * * * * & 417.56 & 434.58 & 0.03 * * * * * & 0.11 & 419.07 & 418.82 \\ \text { APPRO:AS } & 417.08 & 0.29 & 410.34 & 427.89 & 0.11 & 0.00 & 0.11 & 419.10 & 419.00\end{array}$


WSPRO OUTPUT FILE (continued)

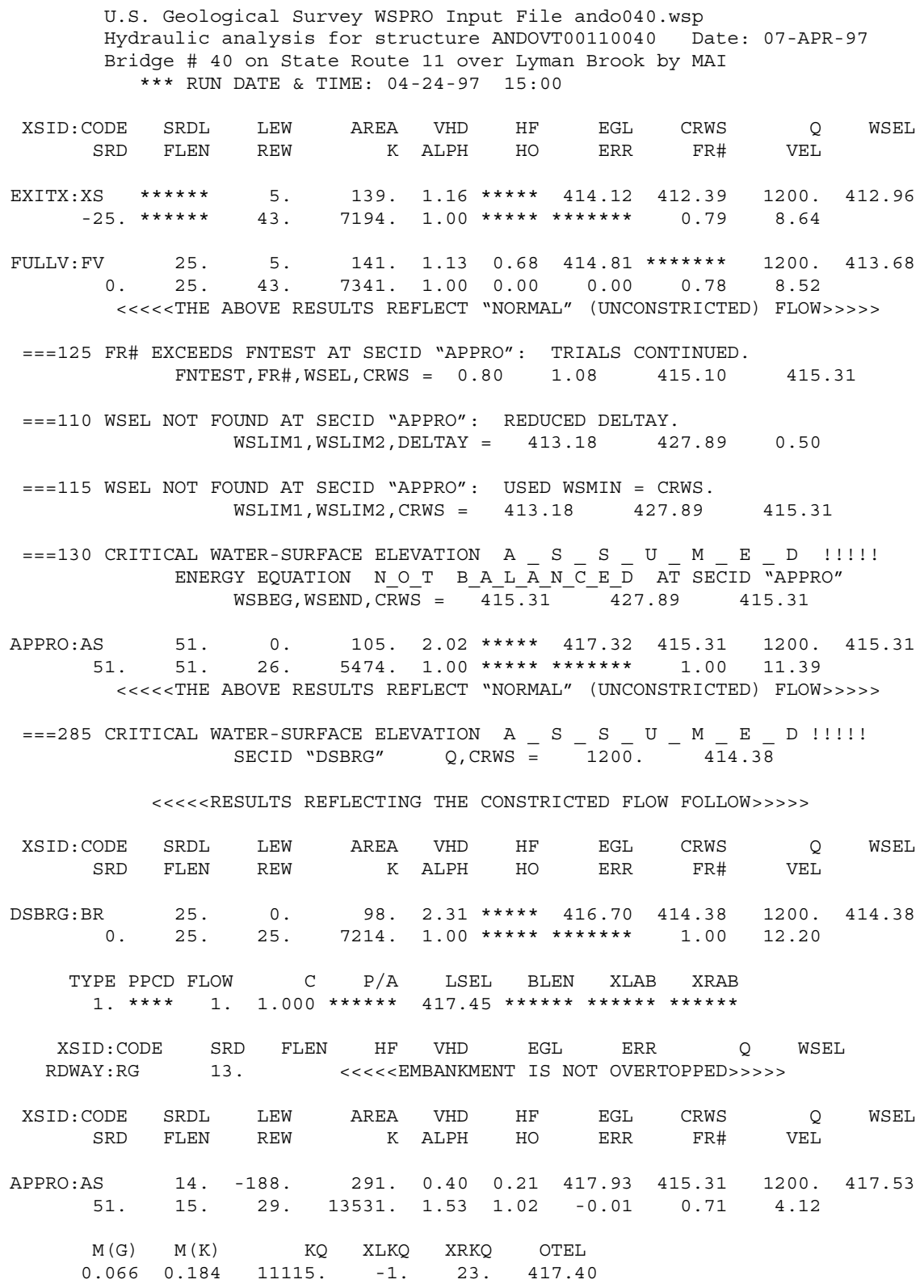

FIRST USER DEFINED TABLE.

\begin{tabular}{|c|c|c|c|c|c|c|c|c|}
\hline XSID : CODE & SRD & LEW & REW & Q & K & AREA & VEL & WSEL \\
\hline EXITX:XS & -25 & 5. & 43. & 1200. & 7194. & 139. & 8.64 & 412.96 \\
\hline FULLV : FV & 0 . & 5. & 43. & 1200. & 7341. & 141 & 8.52 & 413.68 \\
\hline DSBRG : BR & 0 . & 0 . & 25 . & 1200. & 7214. & 98. & 12.20 & 414.38 \\
\hline RDWAY : RG & \multicolumn{3}{|c|}{ 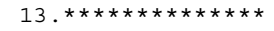 } & \multicolumn{3}{|c|}{ 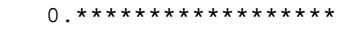 } & \multicolumn{2}{|c|}{$1.00 * * * * * * * *$} \\
\hline APPRO: AS & 51. & -188 & 29. & 1200. & 13531. & 291. & 4.12 & 417.53 \\
\hline XSID : CODE & XLKQ & XRKQ & & & & & & \\
\hline APPRO : AS & -1 & 23 . & 1111 & & & & & \\
\hline
\end{tabular}

SECOND USER DEFINED TABLE.

$\begin{array}{lrrrrrrrrr}\text { XSID:CODE } & \text { CRWS } & \text { FR\# } & \text { YMIN } & \text { YMAX } & \text { HF } & \text { HO } & \text { VHD } & \text { EGL } & \text { WSEL } \\ \text { EXITX:XS } & 412.39 & 0.79 & 408.50 & 435.54 * * * * * * * * * * * * & 1.16 & 414.12 & 412.96 \\ \text { FULLV:FV } & * * * * * * * & 0.78 & 409.17 & 436.21 & 0.68 & 0.00 & 1.13 & 414.81 & 413.68 \\ \text { DSBRG:BR } & 414.38 & 1.00 & 409.27 & 417.49 * * * * * * * * * * * & 2.31 & 416.70 & 414.38 \\ \text { RDWAY:RG } & * * * * * * * * * * * * * * * & 417.56 & 434.58 * * * * * * * * * * * * * * * * * * * * * * * * * * * * * * \\ \text { APPRO:AS } & 415.31 & 0.71 & 410.34 & 427.89 & 0.21 & 1.02 & 0.40 & 417.93 & 417.53\end{array}$




\section{APPENDIX C:}

\section{BED-MATERIAL PARTICLE-SIZE DISTRIBUTION}




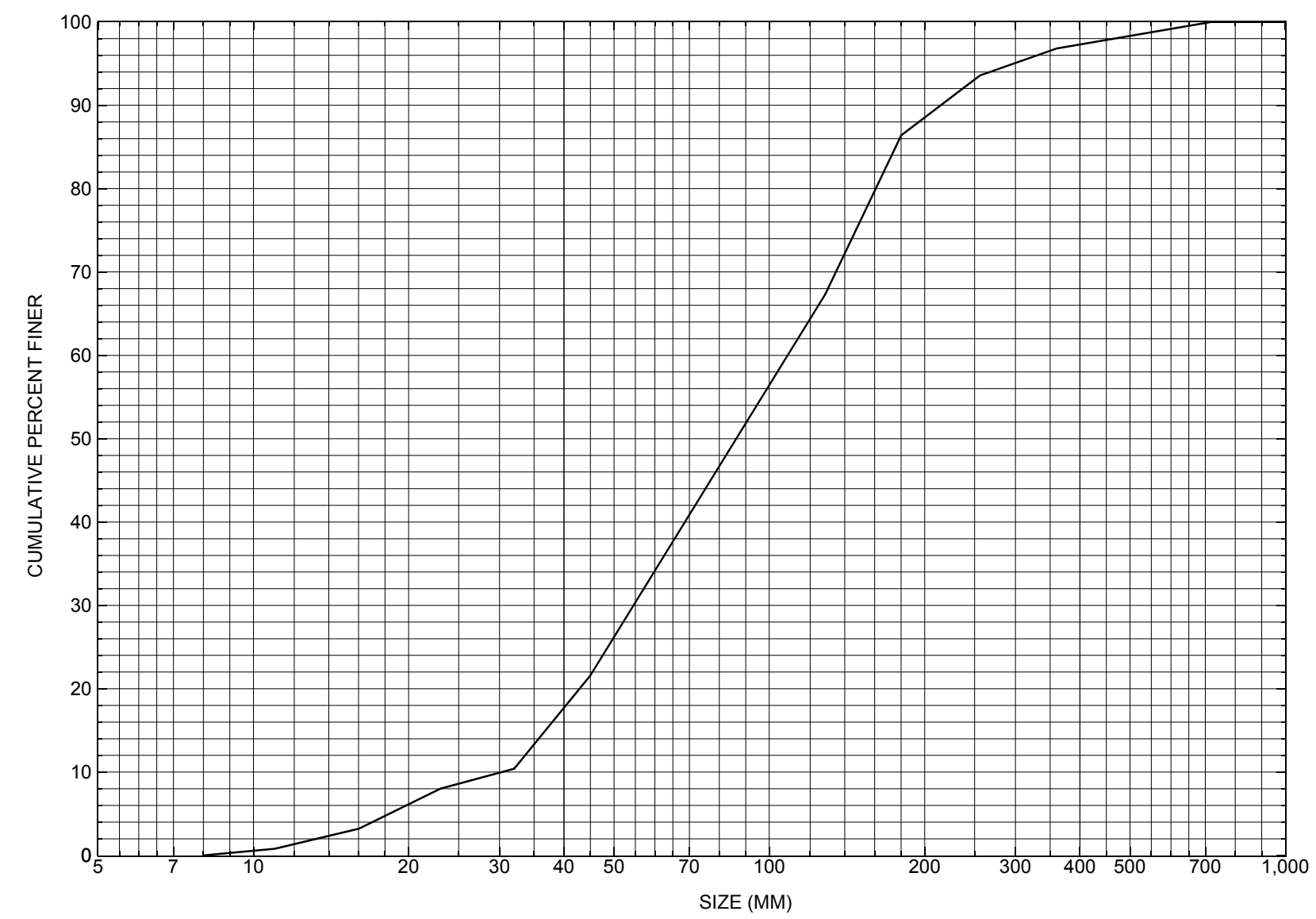

Appendix C. Bed material particle-size distribution for a pebble count in the channel approach of structure ANDOVT00110040, in Andover, Vermont. 


\section{APPENDIX D: \\ HISTORICAL DATA FORM}




\section{Structure Number ANDOVT00110040}

\section{General Location Descriptive}

Data collected by (First Initial, Full last name) $\mathbf{M}$. IVANOFF

Date $(M M / D D / Y Y) \_\mathbf{0 3} / \underline{29} / \underline{95}$

Highway District Number (I - 2; nn) $\mathbf{0 2}$

Town (FIPS place code; I - 4; nnnnn) $\mathbf{0 1 3 0 0}$

Waterway (I - 6) LYMAN BROOK

Route Number VT 11

Topographic Map Andover

Latitude (I - 16; nnnn.n) $\mathbf{4 3 1 5 4}$
County (FIPS county code; I - 3; nnn)

Mile marker (I - 11; nnn.nnn) $\mathbf{0 0 1 8 3 0}$

Road Name (I - 7): -

Vicinity (I - 9) 3.1 MI E JCT VT 121

Hydrologic Unit Code: $\mathbf{0 1 0 8 0 1 0 7}$

Longitude (i - 17; nnnnn.n) $\mathbf{7 2 4 3 1}$

\section{Select Federal Inventory Codes}

FHWA Structure Number $(I-8) \underline{20001600401401}$

Maintenance responsibility $(I-21 ; n n) \quad \mathbf{0 1} \quad$ Maximum span length $(I-48 ; n n n n) \underline{\mathbf{0 0 2 7}}$

Year built (I - 27; YYYY) 1929

Structure length (I - 49; nnnnnn) $\underline{\mathbf{0 0 0 0 2 8}}$

Average daily traffic, ADT (I - 29; nnnnnn) 002736

Deck Width (I - 52; nn.n) $\mathbf{3 4 0}$

Year of ADT (I - 30; YY) $\mathbf{9 2}$

Channel \& Protection $(I-61 ; n)$

Opening skew to Roadway $(I-34 ; n n) \quad \mathbf{3 0}$

Waterway adequacy $(I-71 ; n) \underline{5}$

Operational status $(I-41 ; X) \quad \mathbf{A}$

Underwater Inspection Frequency $(I-92 B ; X Y Y) \_\mathbf{N}$

Structure type (I - 43; nnn) 104

Year Reconstructed (I - 106) 1972

Approach span structure type $(I-44 ; n n n) \quad \mathbf{0 0 0}$

Clear span (nnn.n ft) _

Number of spans (I - 45; nnn) $\underline{\mathbf{0 0 1}}$

Vertical clearance from streambed (nnn.n ft) $\underline{\mathbf{7 . 0}}$

Number of approach spans (I - 46; nnnn) $\mathbf{0 0 0 0}$

Waterway of full opening $\left(n n n . n \mathrm{ft}^{2}\right)$

Comments:

Structural inspection report of $11 / 10 / 93$ indicates a concrete T-beam bridge with an asphalt surface and approaches. Some minor reinforcement is exposed in the spalled area near right abutment. Both concrete abutment stems have minor to moderate staining at the downstream end. The left abutment has a couple of vertical hairline shrinkage cracks with very minor staining. The wingwalls have some newer concrete along the tops; overall, they are in good condition. The footings are not in view. The waterway takes a moderate turn through the structure, then flows into the Middle Branch of the Williams River just downstream. The streambed consists of stone and boulders, with some gravel deposits. 


\section{Bridge Hydrologic Data}

Is there hydrologic data available? $\underline{\mathbf{N}}$ if No, type ctrl-n $h \quad$ VTAOT Drainage area $\left(m i^{2}\right)$ : -

Terrain character:

Stream character \& type: -

Streambed material:

Discharge Data (cfs):

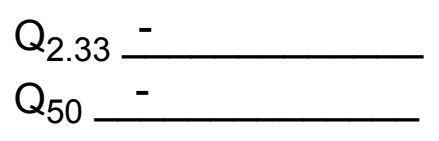

Record flood date $(M M / D D / Y Y):-{ }^{\prime}-$
Estimated Discharge $(c f s):-$

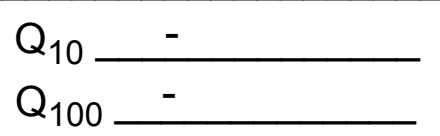

$\mathrm{Q}_{25}$

Water surface elevation $(f t):-$ $(\mathrm{ft} / \mathrm{s}):$

Ice conditions (Heavy, Moderate, Light) : -

Debris (Heavy, Moderate, Light):

The stage increases to maximum highwater elevation (Rapidly, Not rapidly):

The stream response is (Flashy, Not flashy):

Describe any significant site conditions upstream or downstream that may influence the stream's stage: -

Watershed storage area (in percent):

The watershed storage area is: - (1-mainly at the headwaters; 2- uniformly distributed; 3-immediatly upstream oi the site)

Water Surface Elevation Estimates for Existing Structure:

\begin{tabular}{|l|l|l|l|l|l|}
\hline Peak discharge frequency & $Q_{2.33}$ & $Q_{10}$ & $Q_{25}$ & $Q_{50}$ & $Q_{100}$ \\
Water surface elevation (ft)) & - & - & - & - & - \\
Velocity (ft/sec) & - & - & - & - & - \\
\hline
\end{tabular}

Long term stream bed changes: -

Is the roadway overtopped below the $\mathrm{Q}_{100}$ ? (Yes, No, Unknown): $\mathbf{U}$ Frequency: -

Relief Elevation $(f t)$ :

Discharge over roadway at $Q_{100}\left(f t^{3} / \mathrm{sec}\right)$ :

Are there other structures nearby? (Yes, No, Unknown): Upstream distance (miles): Town: If No or Unknown, type ctrl-n os Highway No. :Structure No. : Year Built:

Clear span (ft): Clear Height $(f t)$ : Full Waterway $\left(f^{2}\right)$ : 
Downstream distance (miles): Town: Year Built:

Highway No. : Structure No. : Structure Type:

Clear span (ft): Clear Height $(f t)$ : Full Waterway $\left(f^{2}\right)$ : -

Comments:

\section{USGS Watershed Data}

Watershed Hydrographic Data

Drainage area $(D A)$

4.18 $\mathrm{mi}^{2}$

Watershed storage (ST) ()

Bridge site elevation 1163 $\mathrm{ft}$ $\%$

Main channel length

4.29 $\mathrm{mi}$

$10 \%$ channel length elevation 1220 $\mathrm{ft} \quad 85 \%$ channel length elevation $\mathrm{ft}$

Main channel slope $(S)$

(S) 139.92 $\mathrm{ft} / \mathrm{mi}$

Watershed Precipitation Data

Average site precipitation in

Average headwater precipitation in

Maximum 2yr-24hr precipitation event $(124,2)$ in

Average seasonal snowfall (Sn) $\mathrm{ft}$ 


\section{Bridge Plan Data}

Are plans available? $\mathbf{Y}$ If no, type ctrl-n pl Project Number FA $100 \mathrm{C}$

Date issued for construction (MM/YYYY): 01 / 1971

Low superstructure elevation: USLAB Minimum channel bed elevation: $\mathbf{3 6 0 . 0}$

Benchmark location description:

NO BENCHMARK INFORMATION.

Reference Point (MSL, Arbitrary, Other): Arbitrary Datum (NAD27, NAD83, Other): Arbitrary Foundation Type: 1 (1-Spreadfooting; 2-Pile; 3- Gravity; 4-Unknown)

If 1 : Footing Thickness $\mathbf{2 . 0} \quad$ Footing bottom elevation: $\underline{\mathbf{3 5 4 . 0}}$

If 2: Pile Type: ___ (1-Wood; 2-Steel or metal; 3-Concrete) Approximate pile driven length: -

If 3: Footing bottom elevation: -

Is boring information available? $\mathbf{N}$ If no, type ctrl- $n$ bi Number of borings taken: _-

Foundation Material Type: $\mathbf{3}$ (1-regolith, 2-bedrock, 3-unknown)

Briefly describe material at foundation bottom elevation or around piles:

Plans note: "bottom of footings foundation: boulders"

Comments:

The bridge was widened on the original abutments and wingwalls and now covers part of the wingwalls on the up and downstream sides. There are no elevations on the widening plans but they mention using the bridge seat elevation of the original structure. The bridge is just upstream from the confluence with the Middle Branch of the Williams River. Other elevation points: 1) the top streamward edge of the concrete at the upstream end of upstream left wingwall, elevation 367.5; and 2) the point at the same location described above, but on the downstream right wingwall, elevation 364.0. 


\section{Cross-sectional Data}

Is cross-sectional data available? $\mathbf{N}$ If no, type ctrl-n xs

Source (FEMA, VTAOT, Other)? -

Comments:

\section{NO CROSS SECTION INFORMATION}

\begin{tabular}{|l|l|l|l|l|l|l|l|l|l|l|l|}
\hline Station & - & - & - & - & - & - & - & - & - & - & - \\
\hline Feature & - & - & - & - & - & - & - & - & - & - & - \\
\hline $\begin{array}{l}\text { Low cord } \\
\text { elevation }\end{array}$ & - & - & - & - & - & - & - & - & - & - & - \\
\hline $\begin{array}{l}\text { Bed } \\
\text { elevation }\end{array}$ & - & - & - & - & - & - & - & - & - & - & - \\
\hline $\begin{array}{l}\text { Low cord to } \\
\text { bed length }\end{array}$ & - & - & - & - & - & - & - & - & - & - & - \\
\hline Station & - & - & - & - & - & - & - & - & - & - & - \\
\hline Feature & - & - & - & - & - & - & - & - & - & - & - \\
\hline $\begin{array}{l}\text { Low cord } \\
\text { elevation }\end{array}$ & - & - & - & - & - & - & - & - & - & - & - \\
\hline $\begin{array}{l}\text { Bed } \\
\text { elevation }\end{array}$ & - & - & - & - & - & - & - & - & - & - & - \\
\hline $\begin{array}{l}\text { Low cord to } \\
\text { bed length }\end{array}$ & - & - & - & - & - & - & - & - & - & - & - \\
\hline
\end{tabular}

Source (FEMA, VTAOT, Other)?

Comments: NO CROSS SECTION INFORMATION

\begin{tabular}{|l|l|l|l|l|l|l|l|l|l|l|l|}
\hline Station & - & - & - & - & - & - & - & - & - & - & - \\
\hline Feature & - & - & - & - & - & - & - & - & - & - & - \\
\hline $\begin{array}{l}\text { Low cord } \\
\text { elevation }\end{array}$ & - & - & - & - & - & - & - & - & - & - & - \\
\hline $\begin{array}{l}\text { Bed } \\
\text { elevation }\end{array}$ & - & - & - & - & - & - & - & - & - & - & - \\
\hline $\begin{array}{l}\text { Low cord to } \\
\text { bed length }\end{array}$ & - & - & - & - & - & - & - & - & - & - & - \\
\hline Station & - & - & - & - & - & - & - & - & - & - & - \\
\hline Feature & - & - & - & - & - & - & - & - & - & - & - \\
\hline $\begin{array}{l}\text { Low cord } \\
\text { elevation }\end{array}$ & - & - & - & - & - & - & - & - & - & - & - \\
\hline $\begin{array}{l}\text { Bed } \\
\text { levation }\end{array}$ & - & - & - & - & - & - & - & - & - & - & - \\
\hline $\begin{array}{l}\text { Low cord to } \\
\text { bed length }\end{array}$ & - & - & - & - & - & - & - & - & - & - & - \\
\hline
\end{tabular}




\section{APPENDIX E: \\ LEVEL I DATA FORM}


U. S. Geological Survey

Bridge Field Data Collection and Processing Form

Qa/Qc Check by: EW

Date: $10 / 1 / 96$

\section{Structure Number}

ANDOVT00110040

\section{A. General Location Descriptive}

1. Data collected by (First Initial, Full last name) R. BURNS

2. Highway District Number $\mathbf{0 2}$

County WINDSOR (027)

Mile marker 001830

Waterway (I - 6) LYMAN BROOK

Town ANDOVER (01300)

Route Number VT 11

Road Name -

Hydrologic Unit Code: $\mathbf{0 1 0 8 0 1 0 7}$

3. Descriptive comments:

Located 3.1 miles east of junction with VT 121, 0.05 miles west of Middletown road, and 0.1 miles east of Andover bridge 39.

\section{B. Bridge Deck Observations}
4. Surface cover... LBUS 4
RBUS 4
LBDS 4
RBDS 4
Overall 4

(2b us, ds,lb,rb: 1- Urban; 2- Suburban; 3- Row crops; 4- Pasture; 5- Shrub- and brushland; 6- Forest; 7- Wetland)
5. Ambient water surface... US 2
UB 1
DS 2
(1- pool; 2- riffle)

6. Bridge structure type 1 (1- single span; 2- multiple span; 3- single arch; 4- multiple arch; 5-cylindrical culvert; 6- box culvert; or 7- other)
7. Bridge length $\underline{28}$
(feet)
Span length $\underline{\mathbf{2 7}}$
(feet) Bridge width 34 (feet)

\section{Road approach to bridge:}
8. LB 1
RB 2
( 0 even, 1- lower, 2- higher)
9. LB
RB 1
(1-Paved, 2- Not paved)

10. Embankment slope (run / rise in feet / foot)

US left

US right

\begin{tabular}{|l|l|l|l|}
\hline \multicolumn{2}{|c|}{ Protection } & \multirow{2}{*}{ 13.Erosion } & 14.Severity \\
\cline { 1 - 2 } 11.Type & 12.Cond. & & \\
\hline
\end{tabular}

LBUS

RBUS

RBDS

LBDS

\begin{tabular}{l|l|}
\hline $\mathbf{0}$ & - \\
\hline $\mathbf{0}$ & - \\
\hline $\mathbf{0}$ & - \\
\hline $\mathbf{0}$ & - \\
\hline
\end{tabular}

\begin{tabular}{l}
0 \\
2 \\
2 \\
\hline
\end{tabular}

Bank protection types: 0- none; 1- < 12 inches,

2- $<36$ inches; $3-<48$ inches;

4- < 60 inches; 5- wall / artificial levee

Bank protection conditions: 1- good; 2- slumped;

3- eroded; 4- failed

Erosion: 0 - none; 1- channel erosion; 2 -

road wash; 3- both; 4- other

Erosion Severity: 0 - none; 1- slight; 2- moderate; 3- severe

\section{Channel approach to bridge (BF):}

15. Angle of approach: $\mathbf{2 0}$

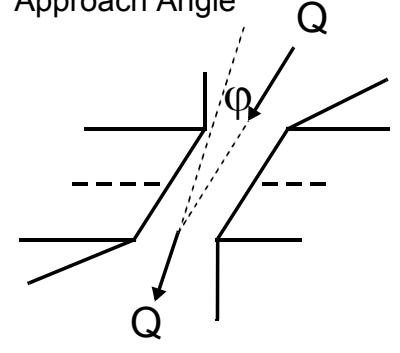

17. Channel impact zone 1 :

Where? RB (LB, RB)

Range? 0 feet US

Channel impact zone 2:

Where? (LB, RB)

Range? feet (US, UB, DS) to feet
Date $(M M / D D / Y Y) \underline{09} / \underline{09} / \underline{1996}$
16. Bridge skew: 0 Bridge Skew Angle

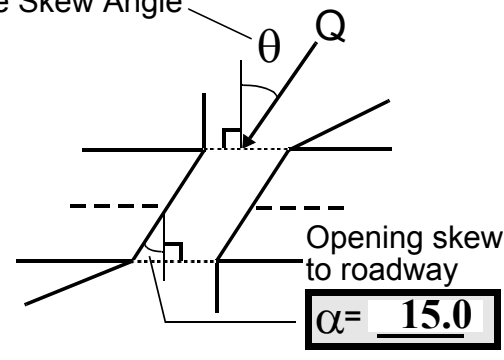
Exist? Y
$(Y$ or $N)$
Severity 1
(US,


18. Bridge Type: 1a

1a- Vertical abutments with wingwalls

1 b- Vertical abutments without wingwalls

2- Vertical abutments and wingwalls, sloping embankment

Wingwalls perpendicular to abut. face

3- Spill through abutments

4- Sloping embankment, vertical wingwalls and abutments

Wingwall angle less than $90^{\circ}$.
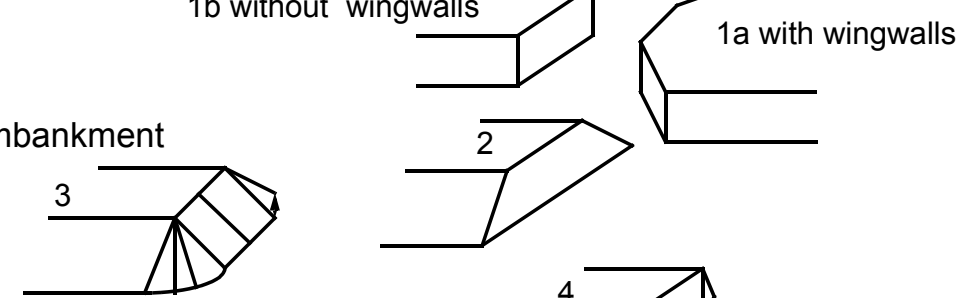

19. Bridge Deck Comments (surface cover variations, measured bridge and span lengths, bridge type variations, approach overflow width, etc.)

\#4: There are trees on the immediate US left and right banks. There is a lawn, gravel parking lot, and Rowell's Inn on the US left bank. There is a gravel driveway, a house and a lawn on the US right bank. Downstream, the banks are grass covered at the confluence of the Middle Branch Williams River.

\#7: Measured bridge length $=29$ feet; bridge span $=27$ feet; and bridge width $=35$ feet.

\section{Upstream Channel Assessment}

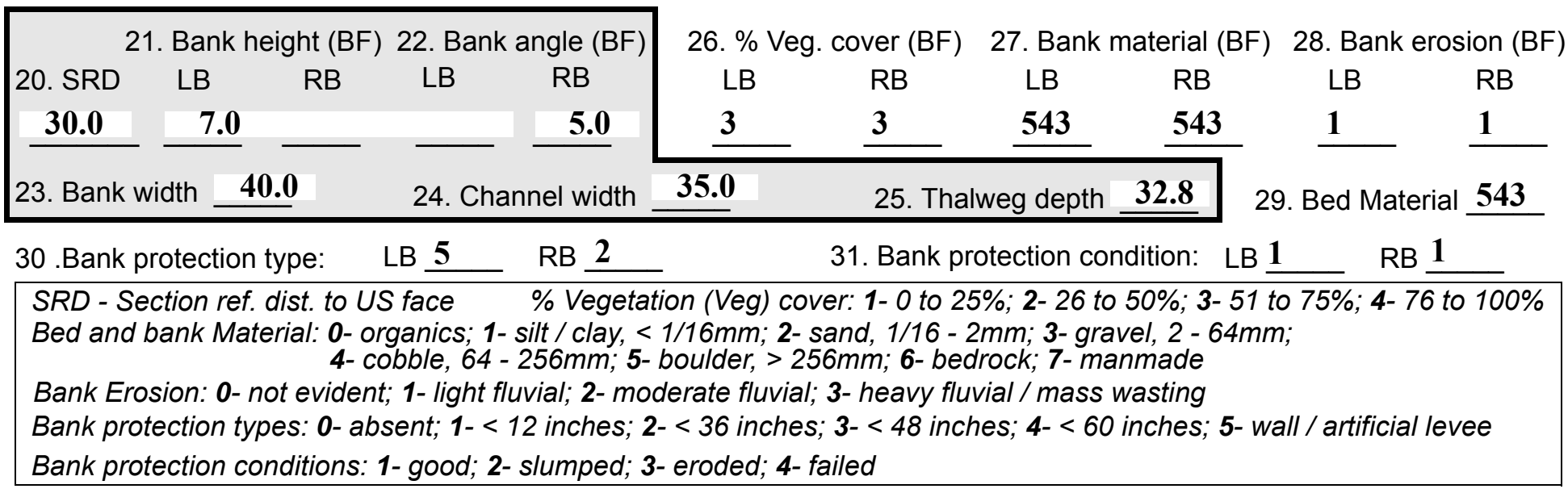

32. Comments (bank material variation, minor inflows, protection extent, etc.):

\#30: The left bank protection is a short stone wall on the top of the bank from 76 feet upstream to 36 feet upstream. On the right bank, there is also type 2 protection from 22 feet upstream to the end of the USRWW. Also from 58 feet upstream to 32 feet upstream, there are rocks piled on top of the USRB. 
36. Point bar extent: $\underline{\mathbf{6 4}}$ feet $\underline{\mathrm{US}}$ (US, UB) to 12 feet $\underline{\mathbf{U S}}$ (US, UB, DS) positioned $\underline{\mathbf{6 0}} \%$ LB to $100 \%$ RB

37. Material: $\mathbf{5 4 3}$

38. Point or side bar comments (Circle Point or Side; Note additional bars, material variation, status, etc.):

There is some grass growing at the US and DS ends. The DS half of the bar is composed of large boulders. The US half of the bar is composed of cobbles. Another point bar extends from $21 \mathrm{ft} \mathrm{US} \mathrm{to} 14 \mathrm{ft}$ DS. The mid-bar distance is at the US bridge face where it is $16 \mathrm{ft}$ wide, and there are two large boulders. The material is comprised of gravel, sand, cobble, and boulder with vines, shrubs and grass growing on top on the DS end.
39. Is a cut-bank present? Y
( $Y$ or if $N$ type $c$ trl-n $c b)$
40. Where? LB (LB or RB)

41. Mid-bank distance: $\mathbf{3 3}$

42. Cut bank extent: 48

eet US

(US, UB, DS)

43. Bank damage: 1

(1- eroded and/or creep; 2- slip failure; 3- block failure)

44. Cut bank comments (eg. additional cut banks, protection condition, etc.):

Some tree roots are exposed on the RB.

\section{Is channel scour present? $\mathbf{N} \quad(Y$ or if $N$ type ctrl-n $c s)$}

47. Scour dimensions: Length Width -

Depth : -

46. Mid-scour distance: -

48. Scour comments (eg. additional scour areas, local scouring process, etc.):

NO CHANNEL SCOUR

49. Are there major confluences? $\mathbf{N}$

51. Confluence 1: Distance Confluence 2: Distance 52. Enters on Enters on 54. Confluence comments (eg. confluence name):

NO MAJOR CONFLUENCES

PVC pipes empty into the stream at 64 feet upstream and 13 feet upstream.
50. How many? -
53. Type- (1-perennial; 2- ephemeral)
Type - (1- perennial; 2- ephemeral)

\section{Under Bridge Channel Assessment}

55. Channel restraint (BF)? LB 2

56. Height (BF)
LB RB
$\mathbf{2 4 . 5}-$
58. Bank width (BF) -
(1- natural bank; 2- abutment; 3- artificial levee)

Bed and bank Material: 0- organics; 1- silt / clay, < 1/16mm; 2- sand, 1/16 - 2mm; 3- gravel, 2 - 64mm; 4- cobble, 64 - 256mm; 5- boulder, > 256mm; 6- bedrock; 7- manmade

Bank Erosion: 0- not evident; 1- light fluvial; 2- moderate fluvial; 3- heavy fluvial / mass wasting

64. Comments (bank material variation, minor inflows, protection extent, etc.):

543

A point bar exists along the left abutment. 
65. Debris and Ice Is there debris accumulation?

67. Debris Potential ( 1- Low; 2- Moderate; 3- High)

69. Is there evidence of ice build-up? 1

70. Debris and Ice Comments:

1
(Yor $N)$ 66. Where? $\mathbf{N}$

68. Capture Efficiency 1

(1- Upstream; 2- At bridge; 3-Both)

Ice Blockage Potential $\mathbf{N}$

(1- Low; 2- Moderate; 3- High)

(1-Low; 2- Moderate; 3- High)

\begin{tabular}{|l|c|c|c|c|c|c|c|c|}
\hline Abutments & $\begin{array}{c}\text { 71. Attack } \\
\angle \mathrm{BF})\end{array}$ & $\begin{array}{c}\text { 72. Slope } \\
(\mathrm{Qmax})\end{array}$ & $\begin{array}{l}\text { 73. Toe } \\
\text { loc. (BF) }\end{array}$ & $\begin{array}{c}\text { 74. Scour } \\
\text { Condition }\end{array}$ & $\begin{array}{c}\text { 75. Scour } \\
\text { depth }\end{array}$ & $\begin{array}{c}\text { 76. Exposure } \\
\text { depth }\end{array}$ & 77. Material & 78. Length \\
\hline LABUT & & - & $\mathbf{9 0}$ & $\mathbf{2}$ & $\mathbf{0}$ & - & - & $\mathbf{9 0 . 0}$ \\
\hline RABUT & $\mathbf{1}$ & $\mathbf{1 0}$ & $\mathbf{9 0}$ & & & $\mathbf{2}$ & $\mathbf{0}$ & $\mathbf{2 4 . 0}$ \\
\hline
\end{tabular}

Pushed: $L B$ or RB

Toe Location (Loc.): 0- even, 1- set back, 2- protrudes

Scour cond.: 0- not evident; 1- evident (comment); 2- footing exposed; 3-undermined footing; 4- piling exposed; 5- settled; 6- failed

Materials: 1- Concrete; 2- Stone masonry or drywall; 3- steel or metal; 4- wood

79. Abutment comments (eg. undermined penetration, unusual scour processes, debris, etc.):

$-$

1

Most of the flow is along the right abutment.

80. Wingwalls:

Exist? Material? Scour Scour Exposure $\begin{array}{lll}81 . & \\ \text { Angle? Length? }\end{array}$ Condition? depth? depth?

USLWW:

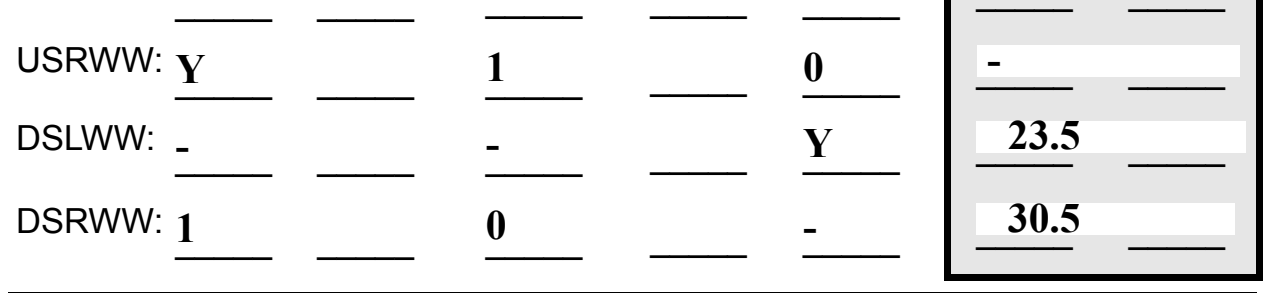

Wingwall materials: 1- Concrete; 2- Stone masonry or drywall; 3- steel or metal; 4- wood

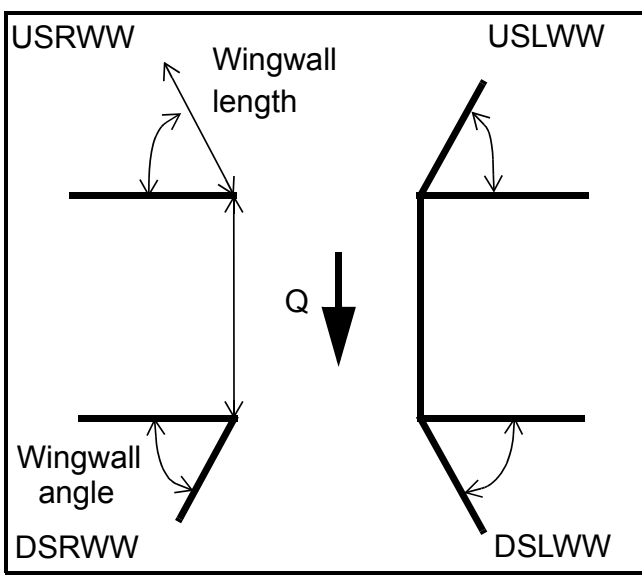

82. Bank / Bridge Protection:

\begin{tabular}{|l|l|l|l|l|l|l|l|c|}
\hline Location & USLWW & USRWW & LABUT & RABUT & LB & RB & DSLWW & DSRWW \\
\hline Type & - & $\mathbf{0}$ & $\mathbf{Y}$ & - & - & $\mathbf{1}$ & - & - \\
\hline Condition & $\mathbf{Y}$ & - & $\mathbf{1}$ & - & - & $\mathbf{2}$ & - & - \\
\hline Extent & $\mathbf{1}$ & - & $\mathbf{0}$ & $\mathbf{0}$ & $\mathbf{2}$ & $\mathbf{0}$ & $\mathbf{0}$ & - \\
\hline
\end{tabular}

Bank / Bridge protection types: 0- absent; 1- < 12 inches; 2- < 36 inches; 3- < 48 inches; 4- < 60 inches; 
83. Wingwall and protection comments (eg. undermined penetration, unusual scour processes, etc.):

-
-
-
-
-
2
1
3
2
1
3

\section{Piers:}

84. Are there piers? ___ (Y or if N type ctrl-n pr)

\begin{tabular}{|l|c|c|c|l|l|l|l|}
\hline \multirow{2}{*}{$\begin{array}{l}85 . \\
\text { Pier no. }\end{array}$} & \multicolumn{3}{|c|}{ width (w) feet } & \multicolumn{5}{c|}{ elevation (e) feet } \\
\cline { 2 - 8 } & w1 & w2 & w3 & e@w1 & e@w2 & e@w3 \\
\hline Pier 1 & & & & $\mathbf{8 5 . 0}$ & $\mathbf{1 2 . 5}$ & $\mathbf{4 0 . 0}$ \\
\hline Pier 2 & & & & $\mathbf{1 1 . 0}$ & $\mathbf{5 5 . 0}$ & $\mathbf{1 6 . 5}$ \\
\hline Pier 3 & & $\mathbf{4 . 0}$ & - & $\mathbf{9 5 . 0}$ & - & - \\
\hline Pier 4 & - & - & - & - & - & - \\
\hline
\end{tabular}

\begin{tabular}{|c|c|c|c|c|}
\hline Level 1 Pier Descr. & 1 & 2 & 3 & 4 \\
\hline 86. Location (BF) & & - & - & - \\
\hline 87. Type & & - & - & - \\
\hline 88. Material & & - & - & - \\
\hline 89. Shape & & - & - & - \\
\hline 90. Inclined? & & - & - & - \\
\hline 91. Attack $\angle(\mathrm{BF})$ & & - & - & - \\
\hline 92. Pushed & & - & - & - \\
\hline 93. Length (feet) & - & - & - & - \\
\hline 94. \# of piles & & - & - & - \\
\hline 95. Cross-members & & - & - & - \\
\hline 96. Scour Condition & & - & - & - \\
\hline 97. Scour depth & $\mathbf{N}$ & - & - & - \\
\hline 98. Exposure depth & - & - & - & - \\
\hline
\end{tabular}

LFP, LTB, LB, MCL, MCM, MCR, RB, RTB, RFP

1- Solid pier, 2-column, 3- bent

1-Wood; 2- concrete; 3- metal; 4- stone

1- Round; 2- Square; 3- Pointed

Y-yes; $N$ - no

$L B$ or $R B$

0- none; 1- laterals; 2- diagonals; 3- both

0- not evident; 1- evident (comment);

2- footing exposed; 3- piling exposed;

4- undermined footing; 5- settled; 6- failed 
99. Pier comments (eg. undermined penetration, protection and protection extent, unusual scour processes, etc.):

-

100.

\section{E. Downstream Channel Assessment}

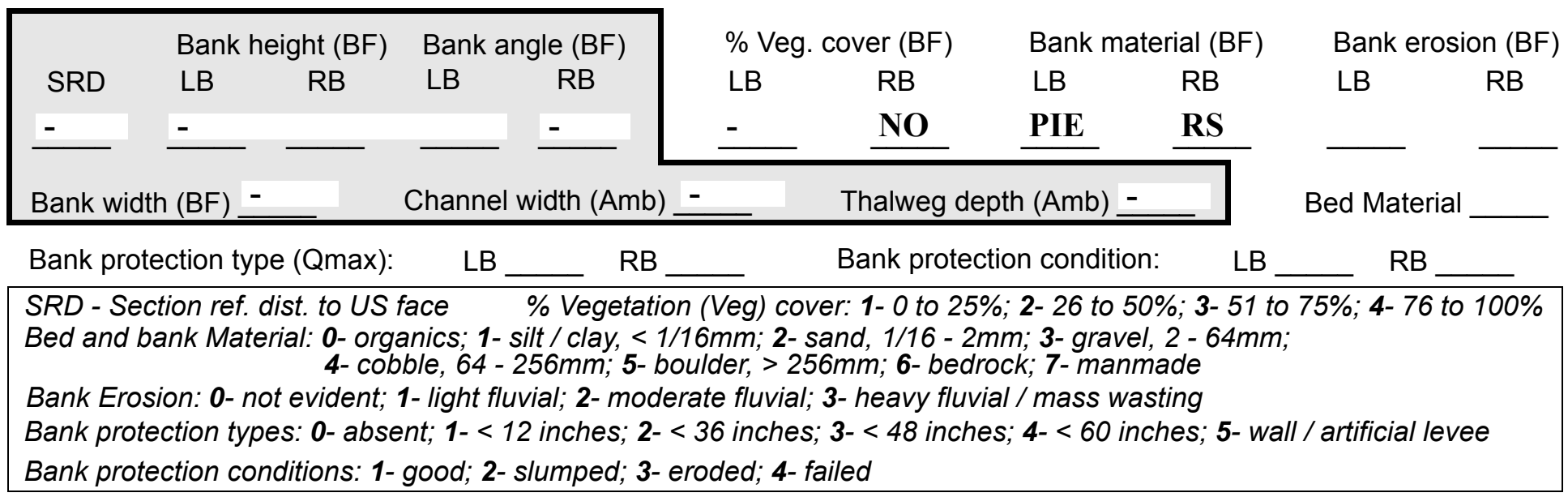

Comments (eg. bank material variation, minor inflows, protection extent, etc.):

1

1

543

543

$\mathbf{0}$

0

543

2

2

1

1

Bank protection on the DSRB goes from the end of DSRWW to 15 feet downstream. On the DSLB, protection also starts at the downstream end of the DSLWW to 10 feet downstream.

101. Is a drop structure present? _ _ ( or $N$, if $N$ type ctrl-n ds) 102. Distance: ___ feet
103. Drop: - feet
104. Structure material:
(1- steel sheet pile; 2- wood pile; 3- concrete; 4- other)

105. Drop structure comments (eg. downstream scour depth): 
Point bar extent: feet

(US, UB, DS) to $\underline{\mathbf{N}}$ feet (US, UB, DS)

DS) positioned \%LB to DR \%RB

Material: $\mathbf{\text { OP }}$

Point or side bar comments (Circle Point or Side; note additional bars, material variation, status, etc.):

\section{STRUCTURE}

Is a cut-bank present? (Y or if $N$ type ctrl- $n$ cb) Where? (LB or $R B)$

Mid-bank distance: $\underline{\mathbf{Y}}$ Cut bank extent: $\underline{15}$ feet $\underline{\mathbf{1 2}}$ (US, UB, DS) to $\underline{\mathbf{0}}$ feet $\underline{\mathrm{DS}}$ (US, UB, DS)

Bank damage: 15 (1- eroded and/or creep; 2- slip failure; 3- block failure)

Cut bank comments (eg. additional cut banks, protection condition, etc.):

DS

50

100

543

Is channel scour present? Poi (Y or if N type ctrl-n cs) Mid-scour distance: $\underline{\text { nt }}$

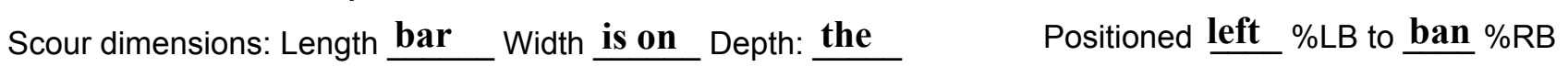

Scour comments (eg. additional scour areas, local scouring process, etc.):

$k$ of the Middle Branch Williams River.

Are there major confluences? $\mathbf{N}$ (Y or if $N$ type ctrl-n $m c)$

Confluence 1: Distance -

Confluence 2: Distance Enters on ( $L B$ or $R B)$

Enters on (LB or $R B)$
How many? -

Type (1- perennial; 2- ephemeral)

Type (1-perennial; 2- ephemeral)

Confluence comments (eg. confluence name):

NO CUT BANKS

\section{F. Geomorphic Channel Assessment}

107. Stage of reach evolution

1- Constructed

2- Stable

3- Aggraded

4- Degraded

5- Laterally unstable

6- Vertically and laterally unstable 
108. Evolution comments (Channel evolution not considering bridge effects; See HEC-20, Figure 1 for geomorphic descriptors):

$\mathbf{N}$

$-$

$-$

$-$

$-$

$-$

NO CHANNEL SCOUR

Y 


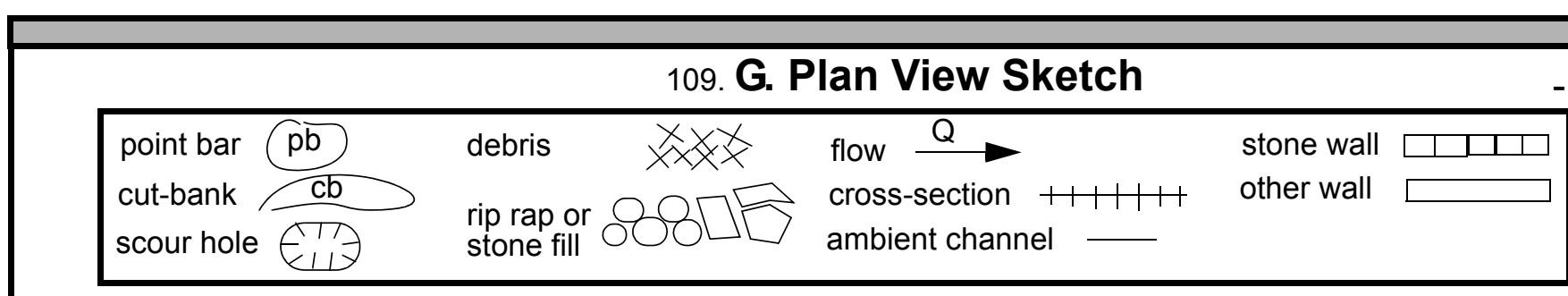

cut-bank $\mathrm{cb}$

scour hole rip rap or stone fill $000 \mathrm{~L}$ cross-section $+1+1+1$ ambient channe other wall 
APPENDIX F:

SCOUR COMPUTATIONS 


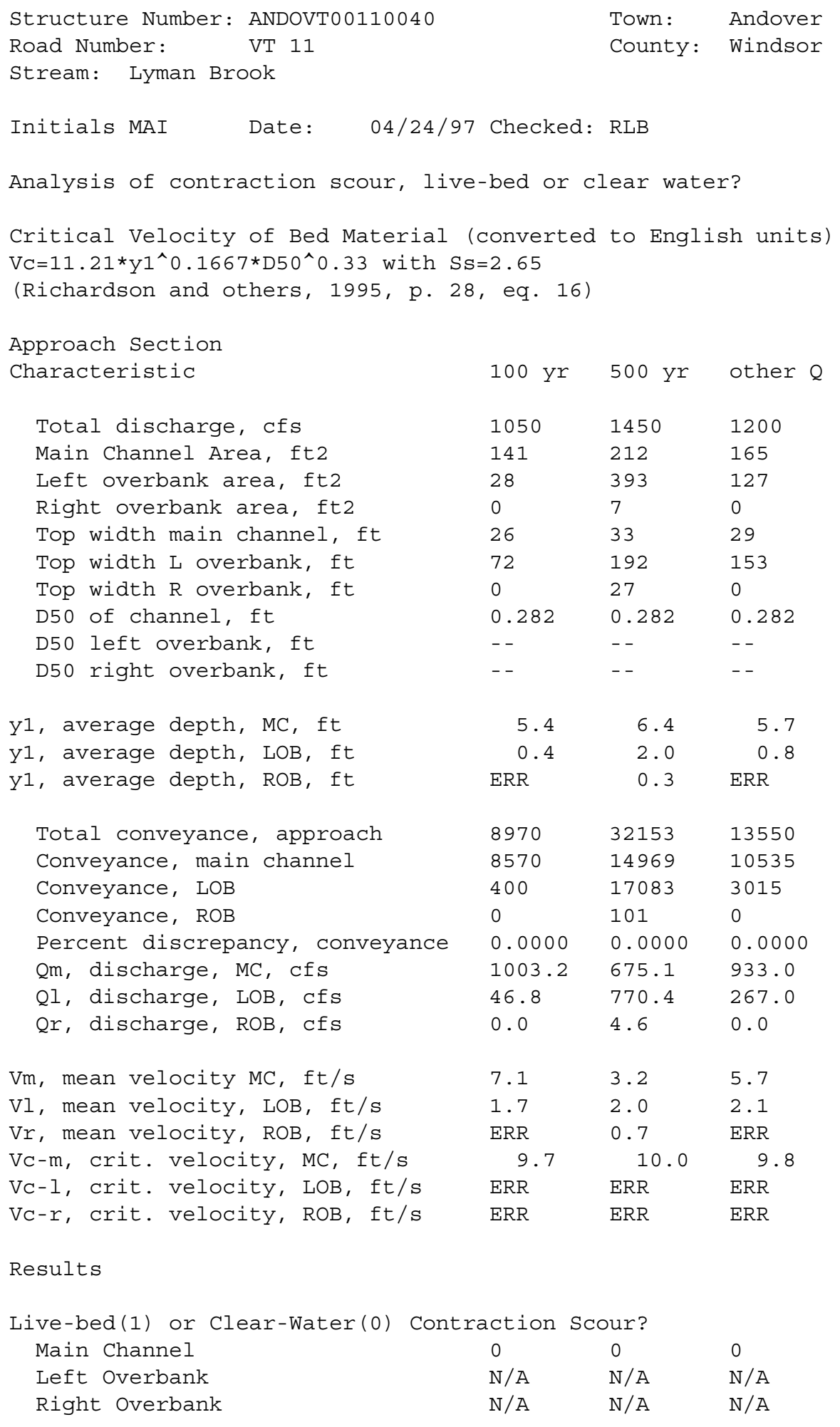


Clear Water Contraction Scour in MAIN CHANNEL

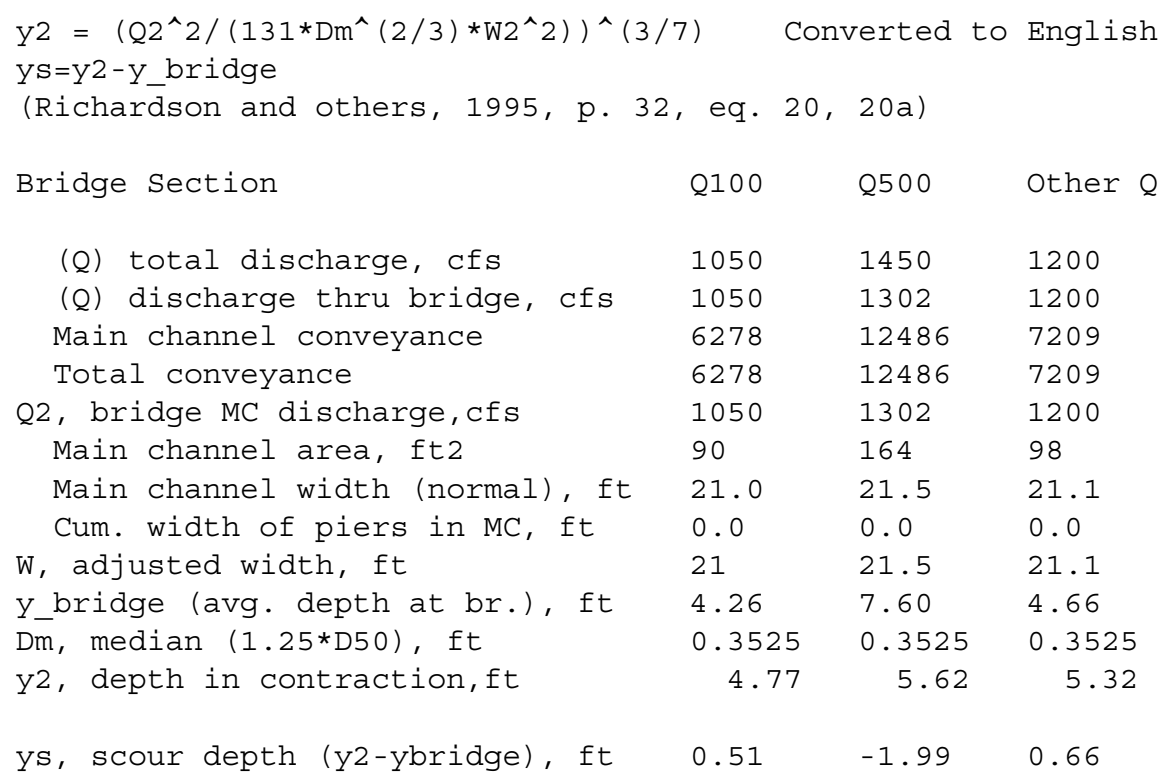

Pressure Flow Scour (contraction scour for orifice flow conditions)

Chang pressure flow equation $\quad \mathrm{Hb}+\mathrm{Ys}=\mathrm{Cq} * \mathrm{qb} / \mathrm{VC}$

$\mathrm{Cq}=1 / \mathrm{Cf} * \mathrm{CC} \quad \mathrm{Cf}=1.5 * \mathrm{Fr}^{\wedge} 0.43 \quad(<=1) \quad \mathrm{CC}=\mathrm{SQRT}[0.10(\mathrm{Hb} /(\mathrm{ya}-\mathrm{w})-0.56)]+0.79 \quad(<=1)$

Umbrell pressure flow equation

$(\mathrm{Hb}+\mathrm{Ys}) / \mathrm{Ya}=1.1021 *[(1-\mathrm{w} / \mathrm{Ya}) *(\mathrm{Va} / \mathrm{Vc})]^{\wedge} 0.6031$

(Richardson and other, 1995, p. 144-146)

Q, total, cfs

Q100 Q500 OtherQ

Q, thru bridge $M C$, cfs

$1050 \quad 1450 \quad 1200$

$\mathrm{Vc}$, critical velocity, ft/s

$1050 \quad 1302 \quad 1200$

Va, velocity MC approach, ft/s $\quad 7.11 \quad 3.18 \quad 5.65$

Main channel width (normal), ft $21.0 \quad 21.5 \quad 21.1$

Cum. width of piers in MC, ft $0.0 \quad 0.0 \quad 0.0$

W, adjusted width, ft

$21.0 \quad 21.5 \quad 21.1$

qbr, unit discharge, ft2/s

$50.0 \quad 60.6 \quad 56.9$

Area of full opening, ft2

$89.5 \quad 163.5 \quad 98.4$

$\mathrm{Hb}$, depth of full opening, ft

Fr, Froude number, bridge MC

$4.26 \quad 7.60 \quad 4.66$

**Area at downstream face, ft2

0.55

$\star *$ Hb depth at downstream face, ft

**Fr, Froude number at DS face ERR 1.17 ERR

**Cf, for downstream face $(<=1.0) \quad \mathrm{N} / \mathrm{A} \quad 1.00 \quad \mathrm{~N} / \mathrm{A}$ 


\begin{tabular}{|c|c|c|c|}
\hline Elevation of Low Steel, ft & 0 & 417.45 & 0 \\
\hline Elevation of Bed, ft & -4.26 & 409.85 & -4 \\
\hline Elevation of Approach, ft & 0 & 419 & 0 \\
\hline Friction loss, approach, ft & 0 & 0.11 & 0 \\
\hline Elevation of WS immediately US, ft & 0.00 & 418.89 & 0.00 \\
\hline ya, depth immediately US, ft & 4.26 & 9.04 & 4.66 \\
\hline Mean elevation of deck, ft & 0 & 420.36 & 0 \\
\hline w, depth of overflow, ft $(>=0)$ & 0.00 & 0.00 & 0.00 \\
\hline Cc, vert contrac correction $(<=1.0)$ & 1.00 & 0.96 & 1.00 \\
\hline$* * \mathrm{Cc}$, for downstream face $(<=1.0)$ & ERR & 0.79 & ERR \\
\hline Ys, scour w/Chang equation, ft & $\mathrm{N} / \mathrm{A}$ & -1.29 & $\mathrm{~N} / \mathrm{A}$ \\
\hline Ys, scour w/Umbrell equation, ft & $\mathrm{N} / \mathrm{A}$ & -2.61 & $\mathrm{~N} / \mathrm{A}$ \\
\hline Nsulbmerced & & & \\
\hline bur w/Chang equation, ft & $\mathrm{N} / \mathrm{A}$ & 3.28 & $\mathrm{~N} / \mathrm{A}$ \\
\hline our w/Umbrell equation, ft & ERR & 0.62 & ERR \\
\hline
\end{tabular}

In UNsubmerged orifice flow, an adjusted scour depth using the Laursen equation results and the estimated downstream bridge face properties can also be computed (ys=y2-ybridgeDs)

$\begin{array}{lllll}\text { y2, from Laursen's equation, ft } 4.77 & 5.62 & 5.32\end{array}$

WSEL at downstream face, ft -- 414.18 --

Depth at downstream face, ft ERR 4.33 ERR

Ys, depth of scour (Laursen), ft N/A 1.28 N/A

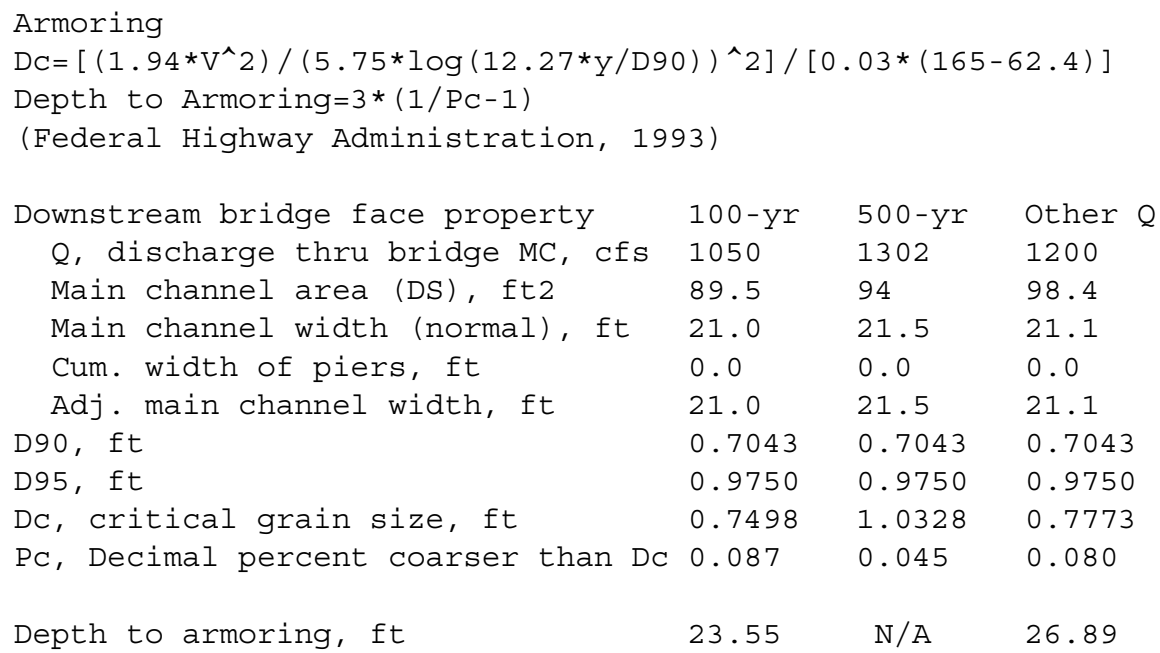

Abutment Scour

Froehlich's Abutment Scour

$\mathrm{Ys} / \mathrm{Y} 1=2.27 * \mathrm{~K} 1 * \mathrm{~K} 2 *\left(\mathrm{a}^{\prime} / \mathrm{Y} 1\right)^{\wedge} 0.43 * \mathrm{Fr} 1 \wedge 0.61+1$

(Richardson and others, 1995, p. 48, eq. 28)

Characteristic

$\mathrm{a}^{\prime}$, abut.length blocking flow, ft

Ae, area of blocked flow ft 2

Qe, discharge blocked abut., cfs
Left Abutment

$100 \mathrm{yr} Q 500 \mathrm{yr} Q$ Other Q $100 \mathrm{yr}$ Q $500 \mathrm{yr}$ Q Other Q

Right Abutment $\begin{array}{llllll}1050 & 1450 & 1200 & 1050 & 1450 & 1200\end{array}$

$\begin{array}{llllll}187.6 & 193.8 & 190 & 3.5 & 36.4 & 6.4\end{array}$

$\begin{array}{llllll}36 & 366.7 & 138.1 & 11.7 & 42.1 & 17.5\end{array}$

$\begin{array}{llllll}77.4 & -- & 299.8 & 47.1 & 70 & 53.3\end{array}$

(If using Qtotal_overbank to obtain Ve, leave Qe blank and enter Ve and Fr manually) 


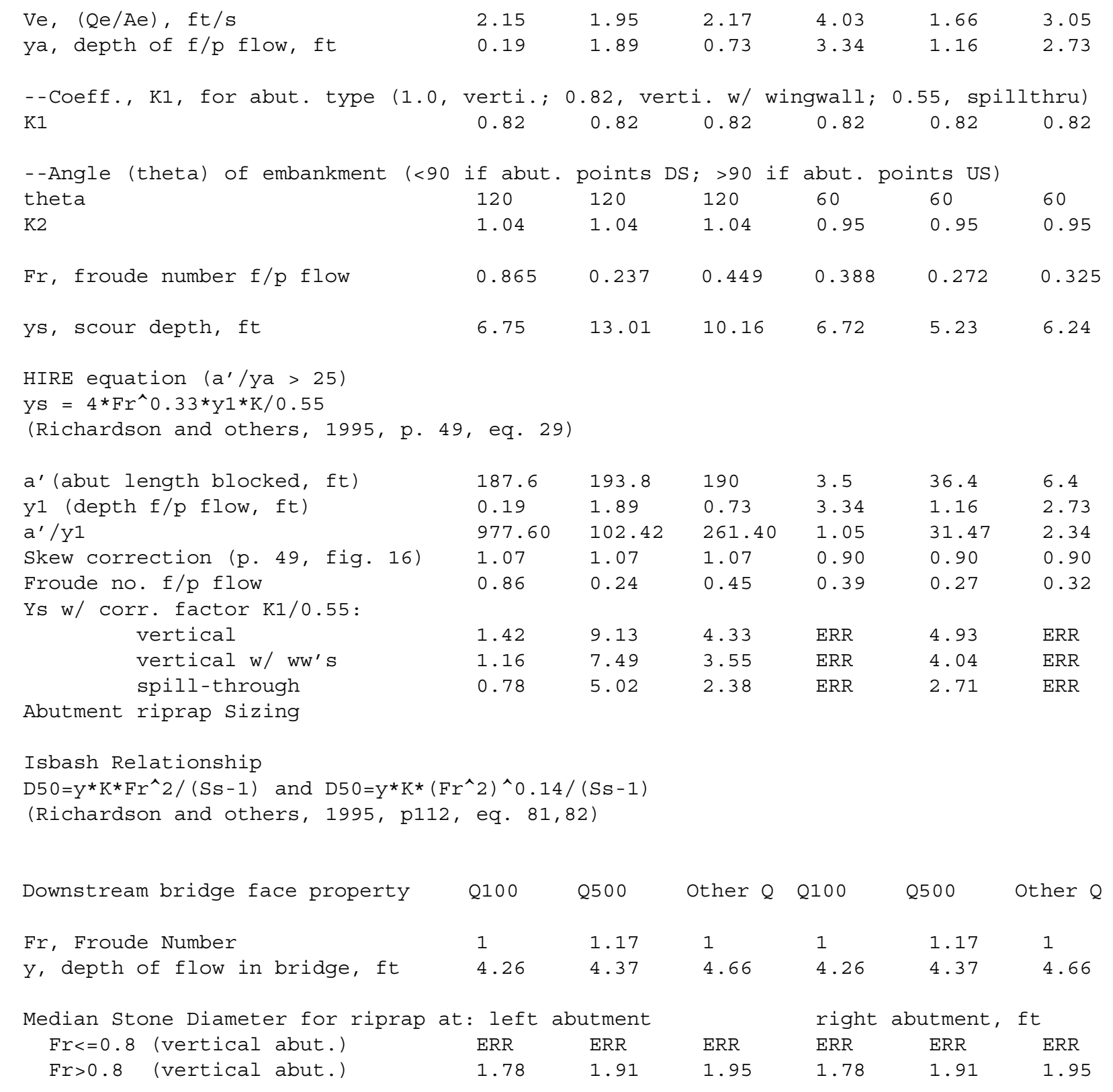


